\title{
Pharmacological Characterization of the Novel and Selective $\alpha 7$ Nicotinic Acetylcholine Receptor-Positive Allosteric Modulator BNC375
}

\author{
Xiaohai Wang, Christopher Daley, Vanita Gakhar, Henry S. Lange, Joshua D. Vardigan, \\ Michelle Pearson, Xiaoping Zhou, Lee Warren, Corin O. Miller, Michelle Belden, \\ Andrew J. Harvey, ${ }^{1}$ Anton A. Grishin, Carolyn J. Coles, Susan M. O'Connor, \\ Fiona Thomson, ${ }^{2}$ Joseph L. Duffy, Ian M. Bell, and Jason M. Uslaner \\ Merck Research Laboratories, Merck \& Co., Inc., Kenilworth, New Jersey (X.W., C.D., V.G., H.S.L., J.D.V., M.P., X.Z., L.W., \\ C.O.M., M.B., F.T., J.L.D., I.M.B., J.M.U.) and Bionomics Limited, Thebarton, Australia (A.J.H., A.A.G., C.J.C., S.M.O.)
}

Received October 30, 2019; accepted February 17, 2020

\section{ABSTRACT}

Treatments for cognitive deficits associated with central nervous system (CNS) disorders such as Alzheimer disease and schizophrenia remain significant unmet medical needs that incur substantial pressure on the health care system. The $\alpha 7$ nicotinic acetylcholine receptor ( $\mathrm{nAChR}$ ) has garnered substantial attention as a target for cognitive deficits based on receptor localization, robust preclinical effects, genetics implicating its involvement in cognitive disorders, and encouraging, albeit mixed, clinical data with $\alpha 7 \mathrm{nAChR}$ orthosteric agonists. Importantly, previous orthosteric agonists at this receptor suffered from off-target activity, receptor desensitization, and an inverted $U$-shaped dose-effect curve in preclinical assays that limit their clinical utility. To overcome the challenges with orthosteric agonists, we have identified a novel selective $\alpha 7$ positive allosteric modulator (PAM), BNC375. This compound is selective over related receptors and potentiates acetylcholine-evoked $\alpha 7$ currents with only marginal effect on the receptor desensitization kinetics. In addition, BNC375 enhances long-term potentiation of electrically evoked synaptic responses in rat hippocampal slices and in vivo. Systemic administration of BNC375 reverses scopolamine-induced cognitive deficits in rat novel object recognition and rhesus monkey object retrieval detour (ORD) task over a wide range of exposures, showing no evidence of an inverted U-shaped dose-effect curve. The compound also improves performance in the ORD task in aged African green monkeys. Moreover, ex vivo ${ }^{13} \mathrm{C}-\mathrm{NMR}$ analysis indicates that BNC375 treatment can enhance neurotransmitter release in rat medial prefrontal cortex. These findings suggest that $\alpha 7 \mathrm{nAChR}$ PAMs have multiple advantages over orthosteric $\alpha 7 \mathrm{nAChR}$ agonists for the treatment of cognitive dysfunction associated with CNS diseases.

\section{SIGNIFICANCE STATEMENT}

BNC375 is a novel and selective $\alpha 7$ nicotinic acetylcholine receptor ( $\mathrm{nAChR}$ ) positive allosteric modulator (PAM) that potentiates acetylcholine-evoked $\alpha 7$ currents in in vitro assays with little to no effect on the desensitization kinetics. In vivo, BNC375 demonstrated robust procognitive effects in multiple preclinical models across a wide exposure range. These results suggest that $\alpha 7 \mathrm{nAChR}$ PAMs have therapeutic potential in central nervous system diseases with cognitive impairments.

\section{Introduction}

Accumulating evidence suggests that the $\alpha 7$ nicotinic acetylcholine receptor ( $\mathrm{AAChR}$ ) may play an essential role in cognitive performance. In the central nervous system (CNS), the $\alpha 7 \mathrm{nAChR}$ is highly expressed in hippocampus, cerebral cortex, and thalamus, brain regions involved in cognitive

\footnotetext{
This work was funded by Merck \& Co., Inc. and Bionomics Limited.

${ }^{1}$ Current affiliation: UniQuest Pty Ltd., Brisbane, Australia.

${ }^{2}$ Current affiliation: Institute of Cancer Sciences, University of Glasgow, Glasgow, United Kingdom.

https://doi.org/10.1124/jpet.119.263483.
}

function, and activation of $\alpha 7 \mathrm{nAChR}$ has been shown to modulate synaptic function and influence the release of a variety of neurotransmitters, such as glutamate, $\gamma$-aminobutyric acid (GABA), ACh, norepinephrine, and dopamine (Livingstone et al., 2009; Huang et al., 2014; Koranda et al., 2014). Preclinical studies in multiple species have demonstrated that enhancing $\alpha 7$ nAChR activity improves cognitive deficits in episodic memory (Sahdeo et al., 2014; Weed et al., 2017), working memory (Ng et al., 2007; Castner et al., 2011), and attention (Pichat et al., 2007; Rezvani et al., 2009), whereas blocking or genetically deleting the receptor is associated with impaired cognitive performance (Keller et al., 2005; Young et al., 2007).

ABBREVIATIONS: ACh, acetylcholine; aCSF, artificial cerebrospinal fluid; AD, Alzheimer disease; AGM, African green monkey; AUC, area under curve E1 first exposure E2 second exposure; fEPSP, field excitatory postsynaptic potentials HEK human embryonic kidney; LTP, long-term potentiation; MLA, methyllycaconitine; mPFC, medial prefrontal cortex; nAChR, nicotinic acetylcholine receptor; NHP, nonhuman primate; ORD, object retrieval detour; PAM, positive allosteric modulator; PS, population spike; TBS, theta-burst stimulation; XTT, 2,3-bis[2-Methoxy-4-nitro-5sulfophenyl]2H-tetrazolium-5-carboxyanilide. 
Furthermore, the expression level of $\alpha 7 \mathrm{nAChR}$ can be affected by several pathologic conditions, including Alzheimer disease (AD) and schizophrenia (Freedman et al., 1995; Guan et al., 2000; Wevers et al., 2000; Kadir et al., 2006). Human genetic evidence indicates that both large deletions to the region of $15 q 13.3$ in chromosome 15 and smaller deletions to the gene for the $\alpha 7 \mathrm{nAChR}$, CHRNA7, frequently produce cognitive impairments (Sharp et al., 2008; Le Pichon et al., 2013).

Various strategies have been aimed at pharmacologically enhancing $\alpha 7 \mathrm{nAChR}$ function to treat cognitive deficits associated with $\mathrm{AD}$ and schizophrenia. One such approach has been to develop orthosteric $\alpha 7 \mathrm{nAChR}$ agonists, which bind to the same site as the endogenous ligand ACh. A variety of $\alpha 7$ full or partial agonists have been developed over the past two decades (Hurst et al., 2013; Bertrand et al., 2015), and several candidates have advanced into clinical trials for the treatment of cognitive deficits associated with schizophrenia and $\mathrm{AD}$. However, despite the strong preclinical evidence and some positive clinical findings, most notably with encenicline demonstrating encouraging results in phase 2 studies for schizophrenia and $\mathrm{AD}$, clinical development of selective $\alpha 7$ agonists has not progressed (Bertrand et al., 2015). It is thought that this has been in large part due to the limitations associated with orthosteric approaches for targeting the $\alpha 7$ nAChR, which include: 1 ) lack of selectivity resulting in doselimiting side-effects, e.g., serotonin 5-HT3 receptor antagonism; 2) desensitization and loss of function with sustained exposure to agonist; and 3) inverted U-shaped dose-response function, which may restrict the efficacy of an $\alpha 7$ agonist to a very specific, narrow range of drug exposure (Deardorff et al., 2015).

Positive allosteric modulators (PAMs) of the $\alpha 7 \mathrm{nAChR}$ bind to a unique binding site on the receptor and potentiate the effects of the endogenous ligand $\mathrm{ACh}$, and they therefore may exhibit an improved clinical profile in comparison with orthosteric $\alpha 7$ agonists. PAMs demonstrate superior selectivity over related Cys-loop superfamily of ligand-gated ion channels through binding to a nonconserved region of the $\alpha 7$ nAChR (Dinklo et al., 2011; Williams et al., 2011) and do not appear to promote receptor desensitization, unlike $\alpha 7$ agonists. Therefore, $\alpha 7$ PAMs may produce efficacy over a wider range of concentrations and maintain efficacy upon repeated dosing. Several structurally distinct $\alpha 7$ PAMs have been identified, and according to their effects on receptor desensitization kinetics, at least two distinct types of PAMs have been described. Type I PAMs, including Compound 6 (AVL-3288), NS1738, and BNC375, potentiate the agonist-induced peak current with only marginal effect on the receptor desensitization kinetics. Type II PAMs, such as PNU120596, RO5126946, JNJ-1930942, and B-973, not only affect peak current but also delay receptor desensitization. So far, only a few $\alpha 7$ PAMs have progressed into clinical evaluation, including JNJ39393406, which has advanced to phase 2 study for smoking cessation (Perkins et al., 2018), and AVL-3288, which has been evaluated in healthy human subjects for effects on neurocognitive performance (Gee et al., 2017).

Here, we characterize the in vitro and in vivo pharmacological properties of a novel and selective $\alpha 7$ nAChR PAM, BNC375. This compound overcomes many of the issues associated with orthosteric agonists. It potentiates $\alpha 7$ currents with Type I-like PAM activity on receptor desensitization kinetics, produces effects in multiple in vivo assays over a broad range of exposures in multiple species, and lacks offtarget activity. In addition, consistent with the effects of $\alpha 7$ nAChR activation on neurotransmitter release, we have demonstrated with ex vivo ${ }^{13} \mathrm{C}-\mathrm{NMR}$ analysis that BNC375 can promote glutamate cycling and metabolism. This finding allows for a translatable measure of target modulation that could be helpful for dose selection in the clinical trials.

\section{Materials and Methods}

Cell Lines. Cell lines were cultured at $37^{\circ} \mathrm{C}$ under $5 \% \mathrm{CO} 2$ in a humidified incubator and dissociated for passaging or electrophysiology assays using Accutase (Innovative Cell Technologies, Inc.). Human embryonic kidney (HEK) human $\alpha$ 7/RIC-3 cells were obtained from Eurofins Inc. and were cultured in DMEM/F-12, $10 \%$ fetal bovine serum, $2 \mathrm{mM}$ glutamine, $1 \%$ nonessential amino acids, $400 \mu \mathrm{g} / \mathrm{ml}$ geneticin, and $0.625 \mu \mathrm{g} / \mathrm{ml}$ puromycin. TE671 cells were obtained from American Type Culture Collection and cultured in DMEM, $10 \%$ fetal calf serum, $10 \mathrm{mM}$ HEPES, $1 \mathrm{mM}$ sodium pyruvate, and $2 \mathrm{mM}$ penicillin-streptomycin-glutamine. HEK human $\alpha 3 \beta 4$ cells were from Merck \& Co., Inc. (Kenilworth, NJ) and cultured in DMEM, 6\% fetal calf serum, $5 \mathrm{U} / \mathrm{ml}$ penicillin, $50 \mu \mathrm{g} / \mathrm{ml}$ streptomycin, $100 \mu \mathrm{g} / \mathrm{ml}$ geneticin, and $40 \mu \mathrm{g} / \mathrm{ml}$ zeocin. HEK human $\alpha 4 \beta 2$ cells were from Bionomics Ltd and cultured in DMEM, $10 \%$ fetal calf serum, $10 \mathrm{mM}$ HEPES, $1 \%$ nonessential amino acids, $1 \mathrm{mM}$ sodium pyruvate, $600 \mu \mathrm{g} / \mathrm{ml}$ geneticin, and $200 \mu \mathrm{g} / \mathrm{ml}$ zeocin. HEK human GABA $_{\mathrm{A}}$ cells were from Bionomics Ltd and were cultured in DMEM/F-12, $10 \%$ fetal calf serum, $10 \mathrm{mM}$ penicillin-streptomycin-glutamine, $2 \mathrm{mM}$ HEPES, and $300 \mu \mathrm{g} / \mathrm{ml}$ geneticin. HEK human $5-\mathrm{HT}_{3 \mathrm{~A}}$ cells were obtained from Bionomics Ltd and were cultured in DMEM, $10 \%$ fetal calf serum, $10 \mathrm{mM}$ HEPES, $1 \%$ nonessential amino acids, $1 \mathrm{mM}$ sodium pyruvate, and $600 \mu \mathrm{g} / \mathrm{ml}$ geneticin.

IonFlux HT Electrophysiology Assays. The IonFlux HT automated patch-clamp platform (Fluxion Biosciences, Alameda, CA) was used to record ion channel currents from recombinant HEK cell lines stably overexpressing human Cys-loop receptors $\alpha 3 \beta 4, \alpha 4 \beta 2, \alpha 7,5$ $\mathrm{HT}_{3 \mathrm{~A}}$, or $\mathrm{GABA}_{\mathrm{A}}$. $\alpha 1$ currents were recorded from TE671 cells where $\alpha 1$ is endogenously expressed. For $\alpha 7$ assays, extracellular solution was $150 \mathrm{mM} \mathrm{NaCl}, 5 \mathrm{mM} \mathrm{KCl}, 2 \mathrm{mM} \mathrm{CaCl}_{2}, 1 \mathrm{mM} \mathrm{MgCl}_{2}, 10 \mathrm{mM}$ HEPES, and $12 \mathrm{mM}$ dextrose, $\mathrm{pH} 7.3$, and intracellular solution was $110 \mathrm{mM}$ Tris dibasic, $28 \mathrm{mM}$ TrisBase, $0.1 \mathrm{mM} \mathrm{CaCl}_{2}, 2 \mathrm{mM} \mathrm{MgCl}_{2}$, $11 \mathrm{mM}$ EGTA, and $4 \mathrm{mM} \mathrm{Mg-ATP,} \mathrm{pH} \mathrm{7.3.} \mathrm{For} \alpha 1, \alpha 3 \beta 4, \alpha 4 \beta 2,5-\mathrm{HT}_{3 \mathrm{~A}}$, and $\mathrm{GABA}_{\mathrm{A}}$ assays, extracellular solution was $137 \mathrm{mM} \mathrm{NaCl}, 5 \mathrm{mM}$

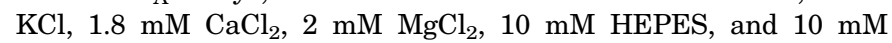
dextrose, $\mathrm{pH} 7.3$, and intracellular solution was $110 \mathrm{mM}$ Tris dibasic, $28 \mathrm{mM}$ TrisBase, $0.1 \mathrm{mM} \mathrm{CaCl} 2,2 \mathrm{mM} \mathrm{MgCl} 2,11 \mathrm{mM}$ EGTA, and $4 \mathrm{mM}$ Na-ATP, pH 7.3. All patch-clamp recordings were conducted at room temperature in the whole-cell population-patch recording configuration. Following cell capture, seal formation, and achieving whole-cell recording, data were acquired at a holding potential of $-60 \mathrm{mV}$ for $5-\mathrm{HT}_{3 \mathrm{~A}}, \alpha 3 \beta 4, \alpha 4 \beta 2, \alpha 7$, and $\mathrm{GABA}_{\mathrm{A}}$ recordings and at $-80 \mathrm{mV}$ for $\alpha 1$ recordings. Sweep lengths were up to 20 seconds in duration and collected at a rate of $5 \mathrm{kHz}$ to allow for the full capture of channel activation and desensitization kinetics.

BNC375 was prepared as $10 \mathrm{mM}$ stock solutions in DMSO and diluted manually for $\alpha 1, \alpha 3 \beta 4, \alpha 4 \beta 2,5-\mathrm{HT}_{3 \mathrm{~A}}$, and $\mathrm{GABA}_{\mathrm{A}}$ assays. For $\alpha 7$ assays, compound titrations were prepared using the Echo acoustic liquid handler (Labcyte Inc., San Jose, CA) in combination with the Mantis liquid handler (Formulatrix, Bedford, MA) and Bravo liquid handler (Agilent, Santa Clara, CA). The final DMSO concentration was $0.3 \%$ in all IonFlux assays. For each patch-clamp recording, a baseline was first established by recording the current response after application of the receptor's natural agonist for 1 second as follows: acetylcholine (ACh) for $\alpha 1, \alpha 3 \beta 4, \alpha 4 \beta 2$, and $\alpha 7$; 5 - hydroxytryptamine (5-HT or serotonin) for $5-\mathrm{HT}_{3 \mathrm{~A}}$ receptor; and GABA for $\mathrm{GABA}_{\mathrm{A}}$ receptor. For $\alpha 7 \mathrm{PAM}$ assays, the $\mathrm{EC}_{20}$ of $\mathrm{ACh}$ was used because it elicited a consistent current response and resulted in 
a robust assay window with adequate dynamic range for the detection of PAM activity; for agonist assays, the test compound was applied in the absence of $\mathrm{ACh}$, and for PAM assays, the test compound was coapplied with $\mathrm{EC}_{20} \mathrm{ACh}$. For $\alpha 1, \alpha 3 \beta 4, \alpha 4 \beta 2$, and $\mathrm{GABA}_{\mathrm{A}}$ receptor assays, the $\mathrm{EC}_{40}$ of $\mathrm{ACh}$ or GABA was used, as it allowed for simultaneous detection of antagonist and PAM activity. For $5-\mathrm{HT}_{3 \mathrm{~A}}$ receptor assay, the $\mathrm{EC}_{80}$ of serotonin was used because it resulted in a consistent and robust current response for the detection of antagonist activity.

After the baseline current response was established, the cells were preincubated with the lowest concentration of BNC375 in a threeconcentration series for approximately 1 minute. The lowest concentration of BNC375 was then coapplied with agonist for 1 second to detect potentiation or inhibition. The preincubation and coapplication procedures were then repeated with the second lowest concentration of BNC375 and then, finally, the highest concentration of BNC375 in the 3-concentration series. $\mathrm{IC}_{50}$ or $\mathrm{EC}_{50}$ was derived from the six-point dose-response curves, where applicable, using standard methods. Agonism, inhibition, and potentiation were calculated as follows, where $\mathrm{I}_{\text {Test }}$ is the current elicited by the test compound alone, $\mathrm{I}_{\text {Control }}$ is the current elicited by the control agonist, and $\mathrm{I}_{\text {Test }}+$ Control is the current elicited by the test compound when coapplied with the control agonist:

$$
\begin{gathered}
\% \text { Agonism }=\left(I_{\text {Test }}\right) /\left(I_{\text {Control }}\right) \times 100 \\
\% \text { Potentiation }=\left(I_{\text {Test }+ \text { Control }}\right) /\left(I_{\text {Control }}\right) \times 100-100 \\
\% \text { Inhibition }=-\left(\left(I_{\text {Test }+ \text { Control }}\right) /\left(I_{\text {Control }}\right) \times 100-100\right)
\end{gathered}
$$

Whole-Cell Patch-Clamp Electrophysiology in GH4C1 Cells. GH4C1 cells stably expressing rat $\alpha 7 \mathrm{nAChRs}$ were patch-clamped in the recording chamber of 16-channel Dynaflow ReSolve chips using EPC10 USB amplifier (HEKA Elektronik, Germany). Extracellular solution was $137 \mathrm{mM} \mathrm{NaCl}, 5 \mathrm{mM} \mathrm{KCl}, 2.5 \mathrm{mM} \mathrm{CaCl}_{2}, 1 \mathrm{mM} \mathrm{MgCl}_{2}$, $10 \mathrm{mM}$ HEPES, and $10 \mathrm{mM}$ D-Glucose, $\mathrm{pH}$ 7.4. Thin wall borosilicate glass electrodes (Harvard Apparatus) were pulled to a resistance of 2-4 $\mathrm{M} \Omega$ when filled with intracellular solution $\left(120 \mathrm{mM} \mathrm{K}^{+}\right.$-gluconate, $5 \mathrm{mM} \mathrm{KCl}, 10 \mathrm{mM}$ HEPES, $10 \mathrm{mM}$ EGTA, $1 \mathrm{mM} \mathrm{MgCl}_{2}, 2 \mathrm{mM}$ ATP, $\mathrm{pH}$ 7.2). Cells were held at $-70 \mathrm{mV}$. Cells with series resistance below $15 \mathrm{M} \Omega$ were kept and $40 \%$ compensation was used routinely. The recording protocol consisted of obtaining two control ACh responses ( $\mathrm{EC}_{20}$ concentration, $250-\mathrm{ms}$ pulse) prior to 30 seconds preincubation with BNC375 $(3 \mu \mathrm{M})$ followed by $250-\mathrm{ms}$ coapplication of $3 \mu \mathrm{M}$ BNC375 plus $\mathrm{EC}_{20} \mathrm{ACh}$. Dose-response for BNC375 was obtained by a continuous application of BNC375 at increasing concentrations alternated with coapplications of BNC375 plus $\mathrm{EC}_{20} \mathrm{ACh}$. The stimulation frequency was one $250-\mathrm{ms}$ coapplication pulse per 30 seconds to ensure complete washout of $\mathrm{EC}_{20} \mathrm{ACh}$ and full recovery of the $\alpha 7$ receptor from ACh-induced desensitization. Current amplitudes along with net current charge (area under curve, AUC) were measured in a Patchmaster software (HEKA Elektronik), and percentage of peak current and AUC potentiation by BNC375 were calculated.

Cytotoxicity Assay. GH4C1 cells expressing rat $\alpha 7 \mathrm{nAChRs}$ were plated on poly-D-lysine-coated 96 -well plates at a density of $10^{5}$ cells/ well in complete growth medium containing $500 \mu \mathrm{M}$ sodium butyrate and placed into a $33^{\circ} \mathrm{C}$ incubator for 48 hours. The medium was then replaced with Hanks' balanced salt solution containing $10 \%$ fetal bovine serum, $100 \mu \mathrm{M}$ choline, and appropriate concentrations of compounds. Cells were incubated for an additional 2 hours at $33^{\circ} \mathrm{C}$. Cell viability was determined using a colorimetric 2,3-bis[2-Methoxy4-nitro-5-sulfophenyl]2H-tetrazolium-5-carboxyanilide (XTT)-based assay (catalog number TOX2; Sigma-Aldrich). After the 2-hour treatment period, compound solutions were replaced with $100 \mu \mathrm{l}$ fresh Hanks' balanced salt solution and $20 \mu \mathrm{l} /$ well XTT $(1 \mathrm{mg} / \mathrm{ml})$. Cells were then incubated for another 4 hours at $37^{\circ} \mathrm{C}$, after which absorbance was measured at $450 \mathrm{~nm}$. Cytotoxicity was calculated relative to the cells treated with vehicle.
Animals. Studies were conducted in strict accordance with the National Research Council's Guide for the Care and Use of Laboratory Animals. Protocols were approved by the Institutional Animal Care and Use Committee of Merck \& Co., Inc.

Hippocampal Slice Preparation. Young adult male SpragueDawley rats (Charles River Laboratory) weighing 200-250 g were housed in an air-conditioned room on a 12-hour light/dark cycle with food and water available ad libitum. On the day of experiments, animals were terminally anesthetized using isoflurane, cervically dislocated, and decapitated. The brain was removed, and 400$\mu \mathrm{m}$-thick hippocampal slices were cut using a microtome (VT1000S; Leica) in ice-cold cutting solution (in millimolars) as follows: 93 NMDG, $2.5 \mathrm{KCl}, 2.5 \mathrm{NaH}_{2} \mathrm{PO}_{4}, 30 \mathrm{NaHCO}_{3}, 20$ HEPES, 25 Glucose, $10 \mathrm{MgSO}_{4}, 0.5 \mathrm{CaCl}_{2}, 5$ sodium ascorbate, 2 thiourea, and 3 sodium pyruvate. Slices were maintained in standard artificial cerebrospinal fluid (aCSF) at $34^{\circ} \mathrm{C}$ for 10 minutes after slicing. After this period, individual slices were transferred to aCSF for 1 hour at room temperature $\left(17-21^{\circ} \mathrm{C}\right)$ and subsequently transferred to a custombuilt chamber continuously perfused with aCSF at a rate of $2-4 \mathrm{ml} /$ min. Standard aCSF (in millimolars) included $127 \mathrm{NaCl}, 1.9 \mathrm{KCl}, 1.2$ $\mathrm{KH}_{2} \mathrm{PO}_{4}, 2.4 \mathrm{CaCl}_{2}, 1.3 \mathrm{MgCl}_{2}, 26 \mathrm{NaHCO}_{3}$, and $10 \mathrm{D}$-glucose, equilibrated with $95 \% \mathrm{O}_{2}-5 \% \mathrm{CO}_{2}$.

Whole-Cell Recording in Hippocampal Interneuron. Wholecell patch-clamp recordings were performed at room temperature from hippocampal interneurons located in the stratum radiatum with a Multiclamp 700B amplifier. Hippocampal interneurons were visualized on a monitor connected to a Hamamatsu C2400 camera mounted on an Olympus BX51 upright microscope using a 40X water immersion lens. Patch pipettes had resistances of between 3 and $8 \mathrm{M} \Omega$ when filled with an intracellular solution of the following composition (in millimolars): $140 \mathrm{~K}$ gluconate, $10 \mathrm{KCl}, 1$ EGTA-Na, $10 \mathrm{HEPES}, 4$ $\mathrm{Na}_{2} \mathrm{ATP}$, and 0.3 GTP. Once electrophysiological confirmation of the neuronal subtype had been conducted via a current-clamp currentvoltage relationship plot, voltage-clamp experiments $(\mathrm{Vh}=-60 \mathrm{mV}$, unless indicated) were carried out in the presence of 2,3-Dioxo-6-nitro1,2,3,4-tetrahydrobenzo[f]quinoxaline-7-sulfonamide (10 $\mu \mathrm{M}), \mathrm{D}-(-)-2-$ Amino-5-phosphonopentanoic acid $(10 \mu \mathrm{M})$, Picrotoxin $(100 \mu \mathrm{M})$, Atropine $(5 \mu \mathrm{M})$, and dihydro-beta-erythroidine $(3 \mu \mathrm{M})$ to isolate $\alpha 7$ nAChR-mediated synaptic events. ACh (100 $\mu \mathrm{M}, 2-5$ seconds) was pressure-ejected at low frequency $(0.017 \mathrm{~Hz})$ via a picospritzer (NPI PDES-02DX) onto recorded neurons using a glass-barreled electrode positioned $\sim 100 \mu \mathrm{m}$ from the recorded neuron.

A baseline of at least five consecutive responses was obtained before applying the test compound. $\alpha 7$-mediated currents were confirmed by testing sensitivity to the selective antagonist methyllycaconitine citrate (MLA, $200 \mathrm{nM}$ ).

Hippocampal Slice LTP. After a 1 hour recovery period in the aCSF, individual slices were transferred to a submersion recording chamber and perfused constantly with warmed $\left(30^{\circ} \mathrm{C}\right)$ oxygenated aCSF at a flow rate of $2-4 \mathrm{ml} / \mathrm{min}$. Schaffer collaterals were stimulated $(0.1 \mathrm{~ms}$ pulse width, $0.033 \mathrm{~Hz}$ ) with a concentric bipolar electrode and the evoked extracellular field excitatory postsynaptic potentials (fEPSPs) recorded from the stratum radiatum of the CA1 region of the hippocampus with a glass capillary microelectrode filled with $2 \mathrm{M}$ $\mathrm{NaCl}$ (resistance 2-6 M $\Omega$ ) using an Axoclamp amplifier.

Stimulation parameters were set to produce an fEPSP of approximately $30 \%-40 \%$ of the maximum amplitude. A 10 -minute stable baseline period (control) was recorded using Axon software (pClamp) followed by administration of test compounds or DMSO control for 15 minutes. The brain slices were then stimulated using a theta-burst stimulation (TBS) protocol for LTP induction (10 mini-trains: four pulses, $100 \mathrm{~Hz}, 200 \mathrm{~ms}$ apart). The test compound was applied for a further 5 minutes. Experiments with unstable baselines were discarded, whereas in successful experiments, fEPSPs were monitored for 60 minutes after LTP induction. All compounds were made as $1000 \times$ stock concentrations in DMSO and diluted to the required concentration in aCSF immediately prior to use. Final DMSO concentration was always $0.1 \%$ in the slice assay. All compounds were 
bath applied. All analysis was conducted using Excel (Microsoft) and Clampfit (MDS Technologies).

In Vivo LTP. Male Sprague-Dawley rats (300-450 g; Charles River Laboratory) were anesthetized initially with isoflurane (5\% in oxygen) and subsequently with an intraperitoneal injection of urethane ( $1 \mathrm{ml} / 100 \mathrm{~g}, 12 \%$ solution), supplemented as necessary. Core body temperature was monitored and maintained at $37^{\circ} \mathrm{C}$ by a homoeothermic blanket system (Harvard Equipment). The left femoral vein and artery as well as the trachea were cannulated to permit 1) administration of supplemental anesthetic, 2) recording of arterial blood pressure via a pressure transducer and amplifier (Neurolog NL108; Digitimer), and 3) maintenance of a clear airway. Animals were placed in a stereotaxic frame (ST-7; Narishige), and the dorsal brain surface overlying the hippocampus was exposed by craniotomy.

Electrodes were lowered vertically through the cortex to the dentate gyrus using the following approximate stereotaxic coordinates. The recording electrode was implanted in the granule cell layer at Bregma $-4 \mathrm{~mm}$, lateral $+2,2.5-3.0 \mathrm{~mm}$ below the pial surface. Electrical stimulation (1-ms pulse width, $0.1 \mathrm{~Hz}$ ) of the perforant pathway was made with a coaxial bipolar stainless-steel electrode to evoke fEPSP and superimposed population spike (PS) activity in the dentate gyrus granule cell layer of the hippocampus recorded through an extracellular carbon fiber microelectrode (Kation Scientific). The amplitude of the PS superimposed on the fEPSP was then calculated and presented in real time. By adjusting the depth of both the stimulating and recording electrode in small increments, the amplitude of the PS was optimized. Thereafter, an input-out curve was generated to determine maximal PS amplitude and the voltage required to obtain a response with an amplitude of approximately $30 \%-50 \%$ of the maximum.

Stimulation parameters were maintained at $30 \%-50 \%$ maximal response at a frequency of $0.033 \mathrm{~Hz}$ to demonstrate a stable baseline period of at least 10 minutes before commencing the full experiment protocol. After baseline recording, BNC375 $(0.1,1$, or $10 \mathrm{mg} / \mathrm{kg})$ or vehicle (30\% Captisol in water) was injected 20 minutes before induction of LTP. The compound was administered via subcutaneous route $(2 \mathrm{ml} / \mathrm{kg})$. LTP induction parameters were as follows: TBS consisted of five train of four pulses (intertrain interval $170 \mathrm{~ms}$, interpulse interval $10 \mathrm{~ms}$ ); upon completion of LTP induction, responses were monitored for a further 60 minutes, and changes in the amplitude of the PS were calculated as a percentage of baseline and expressed as mean \pm S.E.M.

Rat Novel Object Recognition Test. Male Wistar Hannover rats ( $n=7-11$ per group; Charles River Laboratory) weighing 200-300 g were housed two per cage under reverse 12-hour light/dark conditions (lights on 18:00). One hour before testing, animals were brought to the testing room for habituation. Testing was performed during the animal's active phase under dim-light conditions. After the habituation, each rat was given compounds or vehicle before being placed into the test arena for a 5-minute exploration with two identical objects (E1). Scopolamine (1 mg/kg, i.p. in saline) and Donepezil $(1.8 \mathrm{mg} / \mathrm{kg}$, i.p. in saline) were given at 30 minutes prior to $\mathrm{E} 1$. BNC375 (0.01, 0.1, 1, and $10 \mathrm{mg} / \mathrm{kg}$ by mouth in $25 \%$ Cremaphor) was given at 60 minutes prior to $\mathrm{E} 1$. The test arena consisted of a vinyl, opaque cylinder 32 inches in diameter with a 16 -inch wall. The objects used were custom-fabricated geometric shapes (cone and sphere) similar in overall size ( 3 inches in height $\times 3$ inches in diameter). Activity of the rats was video recorded and scored using visual tracking software (Cleversys). Exploration of an object was scored when the animal's nose was pointed in the direction of the object at a distance $<1$ inch. Climbing over or leaning on an object is not considered to be an explorative behavior. After 1 hour intertrial interval, the animals were placed back into the testing arena for 2 minutes of exploration (E2), which now contained one object identical to that used in E1 and another novel object. The amount of time that animals explored the novel object relative to the familiar object was the primary endpoint. In addition, total time spent exploring the objects as well as locomotion during E1 and E2 were also recorded and analyzed. Objects and locations of the object were randomly assigned and counterbalanced across groups. Animals were included in the analysis if the exploration of each object during E1 was $>1$ second, total E1 exploration of both objects was $>4$ seconds, and total exploration of both objects during E2 was $>1$ second.

Object Retrieval Detour Task. To examine the effect of BNC375 on scopolamine-induced cognitive deficits in nonhuman primate (NHP), 11 single-housed male rhesus monkeys (Macaca mulatta), 4-17 kg, participated as subjects in the experiment. The ORD task was also performed in aged male African green monkey (AGM) (17-29 years, $n=8$ ) to access the effect of BNC375 on age-associated cognitive impairments in this animal model of $\mathrm{AD}$ (Cramer et al., 2018). Subjects were maintained on a 12-hour light/dark cycle (lights on at 06:30) with room temperatures maintained at $22 \pm 2^{\circ} \mathrm{C}$. Testing was performed in each subject's home cage between 10:00 and 13:00 hours. The ORD task requires subjects to retrieve food objects (dried fruit) from a clear acrylic box with a single open plane. Sessions consisted of a fixed arrangement of "easy" $(n=8)$ and "difficult" $(n=10)$ trials. For easy trials, the reward was positioned either: 1 ) inside the box with the open plane (and reward) directly in the line of sight of the subject, 2) slightly protruding from the box with the open plane to the left or right of the subject, or 3) just inside the box with the open plane either to the left or right of the subject. The purpose of easy trials was to detect potential adverse events under drug conditions (such as motor, motivational, or visuospatial impairments). For difficult trials, the reward was placed deep inside the box opposite the open plane. Unlike easy trials, performance on difficult trials is disrupted by scopolamine and prefrontal cortex lesions and is thought to require greater attention, planning, and impulse control. A "correct" trial requires the subject to successfully reach into the open plane of the box and retrieve the reward on their first attempt. Trials were scored as "incorrect" if the subject contacted one of the solid planes of the box on the initial attempt. Subjects were not punished for incorrect reaches, and all subjects eventually retrieved all rewards. A newly cleaned box was presented for every trial to eliminate visual cues from the previous handing. Prior to each trial, a barrier was placed in front of the acrylic box to prevent the subject from observing the baiting process or the position of the reward prior to the commencement of each trial. The behavioral assessments were done in real time by an experimenter blinded to the treatment.

Subjects were tested two times weekly, with at least 3 days between test sessions. Subjects were first tested under vehicle-only conditions (intramuscular saline in the case of scopolamine and 30\% Captisol by mouth for BNC375) until their performance stabilized. Next, the subjects were characterized on scopolamine to demonstrate sufficient impairment compared with the vehicle baseline. Because of individual differences in sensitivity to scopolamine, each subject's "best dose" (defined as the dose that produces a $>20 \%$ deficit on difficult trials and does not significantly impact easy trial performance) was identified and subsequently replicated 2 to 3 times to ensure reliability. Once vehicle and scopolamine baseline performance stability were successfully established, BNC375 $(0.1,1$, and $10 \mathrm{mg} / \mathrm{kg}$ by mouth) characterization was initiated. Utilizing a Latin-square study design, scopolamine (or vehicle) and BNC375 (or vehicle) were administered 30 minutes and 2 hours prior to testing, respectively. For the ORD task in AGM, BNC375 (3 mg/kg, IM) or vehicle was administered 30 minutes prior to testing.

Ex Vivo NMR Analysis of ${ }^{13} \mathrm{C}$ Enrichment in Brain Metabolites. Adult male Sprague-Dawley rats (180-250 g; Charles River Laboratory) were acclimated for 1 week and fasted for 12-18 hours prior to the experiment to ensure a fasting glucose level of around $80-100 \mathrm{mg} / \mathrm{dl}$ range. Animals were treated with BNC375 (10 mg/kg by mouth in $25 \%$ Cremophor) or vehicle 90 minutes before ${ }^{13} \mathrm{C}$-glucose (Aldrich) infusion. Tail vein catheterization was conducted under isoflurane anesthesia at 40 minutes prior to ${ }^{13} \mathrm{C}$-glucose infusion. The catheter was connected to a PE50 tube filled with saline and securely taped to the tail. Ketamine ( $30 \mathrm{mg} / \mathrm{kg}$, IP in saline) as a positive control was administrated at 10 minutes before ${ }^{13} \mathrm{C}$-glucose infusion. ${ }^{13} \mathrm{C}$-glucose was delivered at an exponentially decreasing rate for 8 minutes, with the infusion rate tailored to the weight of each rat. 
Eight minutes after ${ }^{13} \mathrm{C}$-glucose infusion, rats were put into a prefilled isoflurane chamber for $\sim 60$ seconds. Once anesthetized, rats were loaded into a water-jacketed rat holder and microwaved at $5 \mathrm{~kW}$ for 1.7 seconds using a directed microwave pulse (Muromachi Microwave Fixation System) to the head to quickly arrest metabolism, allowing brain tissue to be removed without postmortem changes (Stavinoha et al., 1973; Risa et al., 2009; Chowdhury et al., 2017). Immediately following euthanasia, the rat heads were buried in ice for about 5 minutes before the brains were removed and the medial prefrontal cortex (mPFC) dissected. Whole blood $(1 \mathrm{ml})$ was also collected via a cardiac puncture immediately after microwave euthanasia. Samples were then frozen on dry ice and stored at $-80^{\circ} \mathrm{C}$. Frozen brain tissues were then extracted in methanol:water (80:20) solution using a TissueLyser homogenizer (Bead Ruptor Elite; OMNI International NW, Kennesaw, GA). Samples were dried under liquid nitrogen and resuspended in PBS, and the $\mathrm{pH}$ was adjusted to 7.0. Samples were freeze-dried and stored until NMR analysis.

Frozen samples were resuspended in deuterium oxide and transferred to 3-mm NMR tubes. NMR spectra of plasma and cortical extracts were acquired using a Varian $600 \mathrm{MHz}$ spectrometer equipped with a ${ }^{13} \mathrm{C}$-enhanced cold probe. $1 \mathrm{H}$-decoupled ${ }^{13} \mathrm{C} \mathrm{NMR}$ signals from glutamate $\mathrm{C} 4$, glutamine $\mathrm{C} 4$, and GABA $\mathrm{C} 2$ were converted to micromole units by comparison with ${ }^{13} \mathrm{C}$ NMR spectra from reference solutions acquired under identical conditions. Fractional ${ }^{13} \mathrm{C}$ enrichments in plasma glucose were determined using $1 \mathrm{H}$ NMR as previously described (Chowdhury et al., 2012).

Statistics. In all figures, data are presented as means \pm S.E.M. All statistics were performed with the GraphPad Prism 6 (GraphPad Software, Inc.). $P<0.05$ was considered significant. ORD task in AGMs was analyzed with a paired $t$ test. ORD task with scopolamineinduced impairment was analyzed via one-way repeated-measures analysis of variance followed by Fisher's least significant difference post hoc test. For other assays, one-way analysis of variance followed by Fisher's least significant difference post hoc tests were performed to examine group differences.

\section{Results}

Electrophysiological Characterization of BNC375. BNC375 (Fig. 1A) was initially discovered and optimized as a positive allosteric modulator of $\alpha 7 \mathrm{nAChR}$ using $\mathrm{GH} 4 \mathrm{C} 1$ cells stably expressing human $\alpha 7 \mathrm{nAChR}$ (Harvey et al., 2019). Here we use IonFlux HT automated patch-clamp of HEK human $\alpha 7 /$ RIC3 cells to further characterize the effect of BNC375 on $\alpha 7$ nAChR. BNC375 alone does not affect channel opening to a compound concentration up to $10 \mu \mathrm{M}$, confirming that this compound has no intrinsic agonist activity (Fig. 1B). To examine the PAM activity of BNC375, an $\mathrm{EC}_{20}$ concentration of ACh $(40 \mu \mathrm{M})$ was used, as it elicited a consistent current response and resulted in a robust assay window with adequate dynamic range. Application of $\mathrm{EC}_{20} \mathrm{ACh}$ evoked a fast activating and desensitizing current (Fig. 1B), which is in good agreement with the properties reported for $\alpha 7 \mathrm{nAChR}$ (Williams et al., 2011). Preincubation of BNC375 profoundly increased $\mathrm{EC}_{20}$ ACh-induced peak current amplitude by $225 \%, 605 \%$, and $910 \%$ ( $n=7$ patch-clamp recordings $)$ at $1.11,3.33$, and $10 \mu \mathrm{M}$, respectively (Fig. 1, B and C). Notably, BNC375 has little effect on channel activation or desensitization kinetics (Fig. 1B), indicating that this compound is a Type I PAM as reported by the manual patch-clamp recordings from GH4C1 cells (Harvey et al., 2019). Figure 1C shows that BNC375 potentiates $\mathrm{EC}_{20}$ ACh peak current amplitude in a dose-dependent manner with $\mathrm{EC}_{50}=2.64 \mu \mathrm{M}$ and $\mathrm{E}_{\max }=$ $910 \%$. It is worth noting that a concentration higher than $10 \mu \mathrm{M}$ was not evaluated because of low solubility of BNC375.
Therefore, the $\mathrm{E}_{\max }$ and $\mathrm{EC}_{50}$ were calculated based on the dose range tested but may underestimate the value.

In addition to charactering the effect of BNC375 on human $\alpha 7 \mathrm{nAChR}$, BNC375 was further evaluated in GH4C1 cells expressing rat $\alpha 7 \mathrm{nAChR}$ to determine potential species difference in potency. As shown in Fig. 2A, application of $3 \mu \mathrm{M}$ BNC375 potentiated $\mathrm{EC}_{20}$ ACh peak current amplitude by $1386 \%$. The concentration-response measurements of BNC375 for potentiating $\mathrm{EC}_{20} \mathrm{ACh}$-evoked peak current and net current charge (AUC) yielded an $\mathrm{EC}_{50}=1.9 \mu \mathrm{M}$ and 1.3 $\mu \mathrm{M}$, respectively, suggesting the potency of BNC375 at rat $\alpha 7$ nAChR is closely aligned with human $\alpha 7 \mathrm{nAChR}$ pharmacology (Fig. 2B). Figure 2C shows the concentration-response relationships for $\mathrm{ACh}$ in the absence or presence of $2 \mu \mathrm{M}$ BNC375, indicating that BNC375 increased the maximal response and potency of ACh.

Selectivity of BNC375. BNC375 was evaluated for PAM or antagonist activity on other Cys-loop receptors with significant homology to the $\alpha 7 \mathrm{nAChR}$ (Table 1). The $\alpha 1$, $\alpha 3 \beta 4, \alpha 4 \beta 2,5-\mathrm{HT}_{3 \mathrm{~A}}$, and $\mathrm{GABA}_{\mathrm{A}}$ assays used an $\mathrm{EC}_{40}$ concentration of their respective ligands (acetylcholine, serotonin, or GABA) to measure potentiation and antagonism, and 5 - $\mathrm{HT}_{3 \mathrm{~A}}$ antagonism was assessed using an $\mathrm{EC}_{80}$ concentration of serotonin. BNC375 up to $10 \mu \mathrm{M}$ did not show PAM activity at any of the five related receptors. In the antagonist mode, BNC375 also demonstrates good selectivity over other Cysloop receptors (Table 1).

Potentiation of Native $\alpha 7 \mathrm{nAChR}$ Current in Hippocampal Interneurons by BNC375. To assess the effects of BNC375 on native $\alpha 7 \mathrm{nAChRs}$, and to confirm that the effect in native tissue is consistent with the effects observed in the cell lines overexpressing $\alpha 7$ receptors, BNC375 was evaluated using whole-cell voltage-clamp recordings from morphologically and electrophysiologically identified GABAergic interneurons located within the stratum radiatum of rat hippocampus. The pharmacologically isolated $\alpha 7$ currents were induced by pressure-ejected application of ACh (2-5 seconds) onto recorded interneurons using a glass electrode positioned $\sim 100 \mu \mathrm{m}$ from the recording site (Fig. 3A). Brief application of $100 \mu \mathrm{M}$ ACh evoked a fast desensitizing current, which can be blocked by $200 \mathrm{nM}$ of MLA, indicating the current is mediated by $\alpha 7$ receptors (Fig. 3A). Bath application of BNC375 at $3 \mu \mathrm{M}$ potentiated the ACh-evoked $\alpha 7$ currents without influencing the channel kinetics (Fig. 3A). Time plot graphs demonstrate that bath application of BNC375 at $3 \mu \mathrm{M}$ potentiated $\alpha 7$ peak current amplitude and mean net current charge in a time-dependent manner, which is likely due to the slow penetration of BNC375 through the hippocampal slice to the recording site (Fig. 3, B and C). Importantly, the effects of BNC375 can be completely blocked by bath application of $200 \mathrm{nM}$ MLA (Fig. 3, B and C). Initially, the effects of four concentrations of BNC375 were tested upon ACh-evoked $\alpha 7$ currents. Thirty-minute bath application of BNC375 potentiated peak current amplitude and mean net current charge in a concentration-dependent manner (Fig. 3, $\mathrm{D}$ and $\mathrm{E})$. At 3 and $10 \mu \mathrm{M}, \mathrm{BNC} 375$ significantly potentiated the peak current amplitude to $142.3 \% \pm 21 \%(P<0.05)$ and $181.2 \% \pm 24.5 \%(P<0.01)$ of baseline values, respectively (Fig. 3D). BNC375 at 1,3 , and $10 \mu \mathrm{M}$ also significantly potentiated net current charge to $168.3 \% \pm 38.9 \%(P<$ $0.05), 190 \% \pm 28.8 \%(P<0.05)$, and $485.5 \% \pm 181.1 \%(P<$ 0.05 ) of baseline, respectively (Fig. $3 \mathrm{E}$ ). At the lowest 
A<smiles></smiles>

C

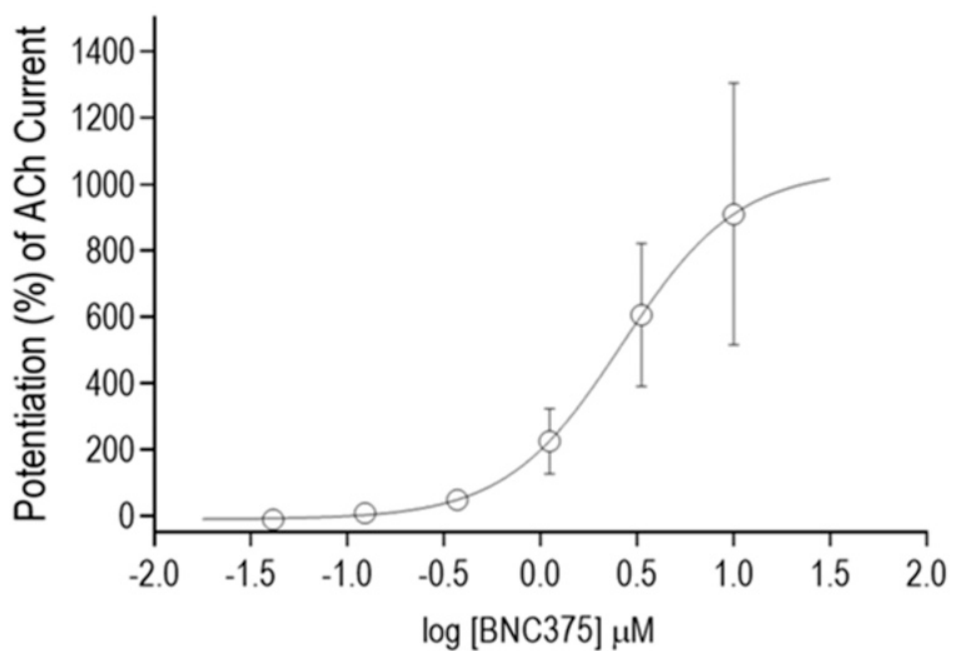

B

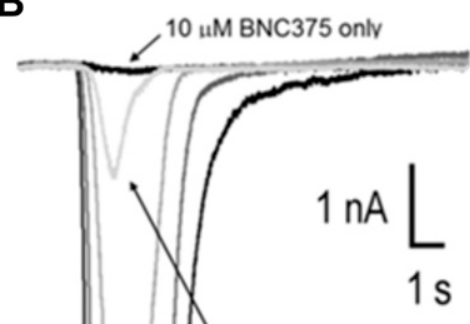

ACh only

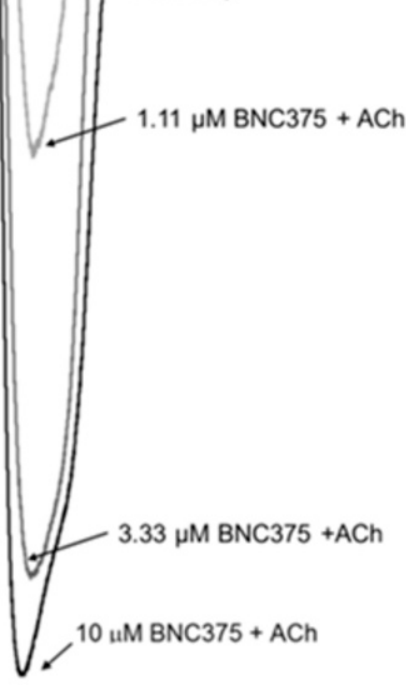

Fig. 1. IonFlux HT automated patch-clamp of HEK human $\alpha 7 /$ RIC3 cell line reveals that BNC375 potentiates ACh-evoked $\alpha 7$ currents in a dosedependent manner. (A) Chemical structure of BNC375. (B) Representative traces showing the effects of BNC375 on $\alpha 7$ currents evoked by 1 -second application of $\mathrm{EC}_{20} \mathrm{ACh}$. BNC375 alone has no effect on $\alpha 7$ current. (C) BNC375 dose-dependently potentiates ACh-evoked $\alpha 7$ peak currents up to $910 \%$ with an $\mathrm{EC}_{50}$ of approximately $2.6 \mu \mathrm{M}(n=7)$.

concentration tested $(0.3 \mu \mathrm{M})$, with a 30 -minute bath application of BNC375, little effect of the compound was observed. To determine if prolonged incubation may further enable the compound to access the recording site, experiments were performed with an increased application time of 60-90 minutes with 0.03 and $0.3 \mu \mathrm{M}$ BNC375. With the prolonged application, BNC375 at $0.3 \mu \mathrm{M}$ significantly potentiated peak current amplitude to $159.6 \% \pm 32.7 \%(P<0.05)$ and net current charge to $228.3 \% \pm 52.2 \%(P<0.01)$ of baseline values (Fig. 3, $\mathrm{D}$ and $\mathrm{E})$.
BNC375 Enhances LTP in Hippocampal Slice. $\alpha 7$ nAChR is highly expressed in hippocampus across multiple species, including mouse, rat, monkey, and human (Séguéla et al., 1993; Breese et al., 1997; Whiteaker et al., 1999; Han et al., 2003). In addition, enhancement of synaptic transmission has been observed in rodent hippocampal slices with both $\alpha 7$ agonists and PAMs (Biton et al., 2007; Welsby et al., 2009; Dinklo et al., 2011). To evaluate the effects of $\alpha 7 \mathrm{nAChR}$ activation on long-term synaptic plasticity and compare the effects of PAMs versus an agonist, BNC375, PNU120596, and
A

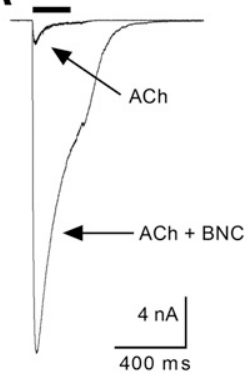

B

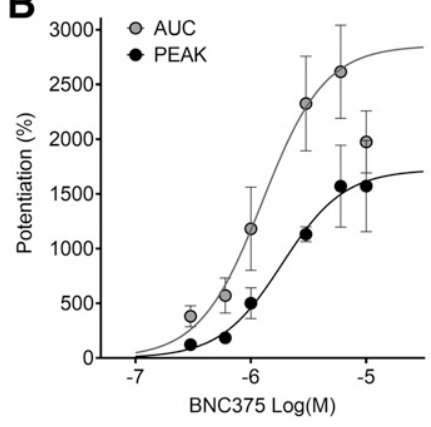

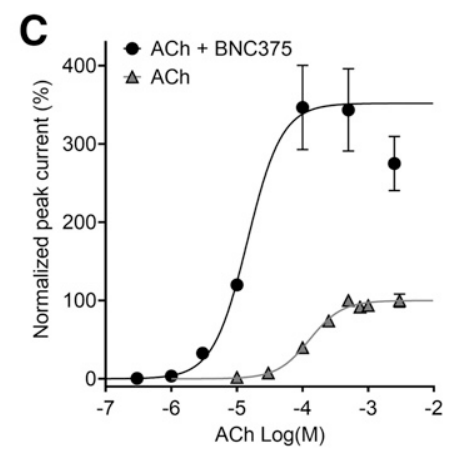

Fig. 2. BNC375 potentiates ACh-evoked $\alpha 7$ currents in GH4C1 cells stably expressing rat $\alpha 7 \mathrm{nAChR}$. (A) Representative traces of $\alpha 7$ currents evoked by $\mathrm{EC}_{20} \mathrm{ACh}$ in the absence or presence of 3 $\mu \mathrm{M}$ BNC375. (B) Concentration-response relationship showing potentiation of $\alpha 7$ peak current and net current charge (AUC) by BNC375. For peak current potentiation, $\mathrm{EC}_{50}=1.9 \mu \mathrm{M}, \mathrm{n}_{\mathrm{H}}=1.6$, and maximum effect $\left(\mathrm{E}_{\max }\right)=1572 \%$. For AUC potentiation, $\mathrm{EC}_{50}=1.3 \mu \mathrm{M}, \mathrm{n}_{\mathrm{H}}=$ 1.6, and Emax $=2616 \%$. (C) Effects of BNC375 on the ACh concentrationresponse curve. Plot of the peak AChevoked currents by $\mathrm{ACh}$ alone $\left(\mathrm{EC}_{50}=\right.$ $\left.127.7 \mu \mathrm{M}, \mathrm{n}_{\mathrm{H}}=1.8\right)$ and in the presence of $2 \mu \mathrm{M} \mathrm{BNC} 375\left(\mathrm{EC}_{50}=14.5 \mu \mathrm{M}, \mathrm{n}_{\mathrm{H}}=1.7\right.$, data normalized to $\mathrm{EC}_{100} \mathrm{ACh}$ current). 
TABLE 1

Selectivity of BNC375 against other Cys-loop family of ligand-gated ion channels

\begin{tabular}{lcc}
\hline Cys-loop receptor & PAM EC $_{50} \mu \mathrm{M}$ & Antagonist $\mathrm{IC}_{50} \mu \mathrm{M}$ \\
\hline $\mathrm{nAChR} \alpha 1$ & $>10$ & $>10$ \\
$\mathrm{nAChR} \alpha 3 \beta 4$ & $>10$ & 4.70 \\
nAChR $\alpha 4 \beta 2$ & $>10$ & $>10$ \\
nAChR $\alpha 7$ & 2.64 & $>10$ \\
GABA $_{\mathrm{A}}$ & $>10$ & $>10$ \\
$5-\mathrm{HT}_{3 \mathrm{~A}}$ & $\mathrm{ND}$ & 6.47 \\
\hline
\end{tabular}

encenicline were tested for their impact on LTP induced by TBS (Fig. 4). Extracellular fEPSPs were recorded from the stratum radiatum of the CA1 region in response to Schaffer collateral stimulation. Under vehicle control conditions (0.1\% DMSO), LTP was induced by TBS as measured by a potentiation of the fEPSP amplitude to $119.1 \% \pm 4.1 \%$ of baseline (Fig. 4A). Although the bath application of BNC375 had no effect on ongoing evoked fEPSP, the compound dosedependently enhanced LTP (Fig. 4A). At 3 and $10 \mu \mathrm{M}$, BNC375 significantly increased fEPSP amplitude to $139.2 \% \pm 5.3 \%(P<0.05)$ and $162.5 \% \pm 10.1 \%(P<0.01)$ of baseline, respectively (Fig. 4, A and D). In contrast, the $\alpha 7$ partial agonist encenicline enhanced LTP at $30 \mathrm{nM}(151.1 \% \pm$ $20.7 \%, P<0.05)$ but attenuated LTP at $300 \mathrm{nM}(97.9 \% \pm$ $8.6 \%, P=0.1$ ) (Fig. 4, B and D). The inverted U-shaped concentration response is likely due to desensitization of $\alpha 7$ $\mathrm{nAChR}$ by sustained encenicline exposure at the high concentration, as has been shown with $\alpha 7$ agonists, including encenicline, in various other preparations (Prickaerts et al., 2012; Weed et al., 2017). In addition to BNC375 and encenicline, we also evaluated the effects of a Type II PAM PNU120596 on hippocampal LTP. Similar to BNC375, PNU120596 enhanced LTP from 0.3 to $10 \mu \mathrm{M}$ in a dose-dependent manner (Fig. 4, C and D).

BNC375 Enhances LTP In Vivo. To understand the effect of $\alpha 7$ PAM on long-term synaptic plasticity in vivo, we
A

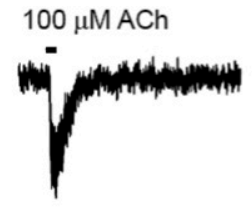

Control

B

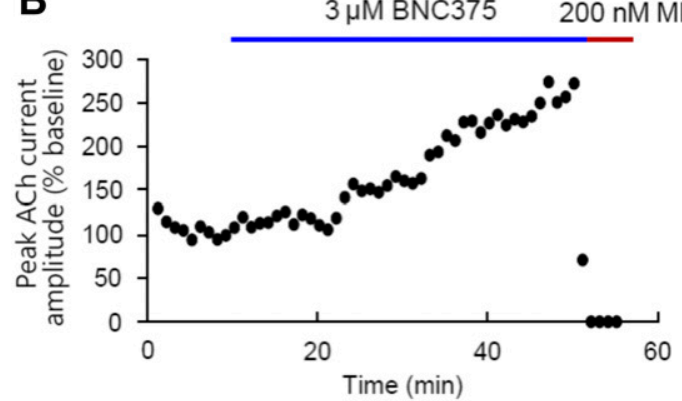

D

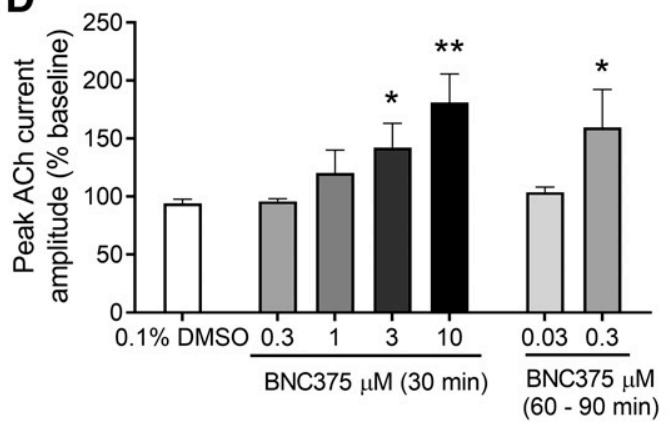

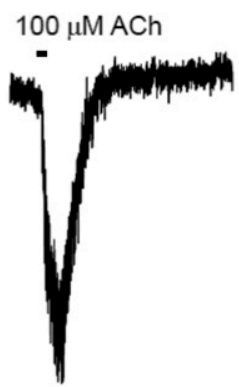

$3 \mu \mathrm{M}$ BNC375
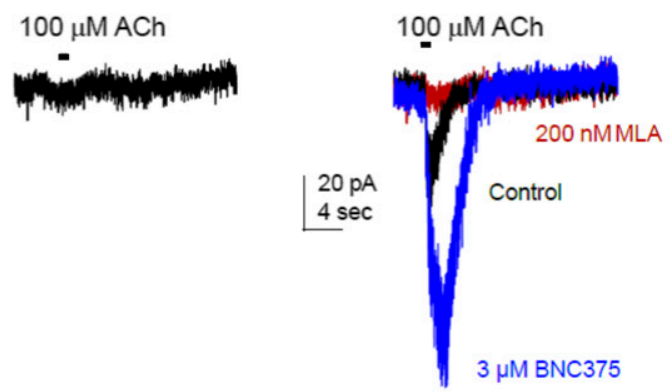

200 nM MLA

C

$3 \mu \mathrm{M} \mathrm{BNC375} \quad 200 \mathrm{nM}$ MLA

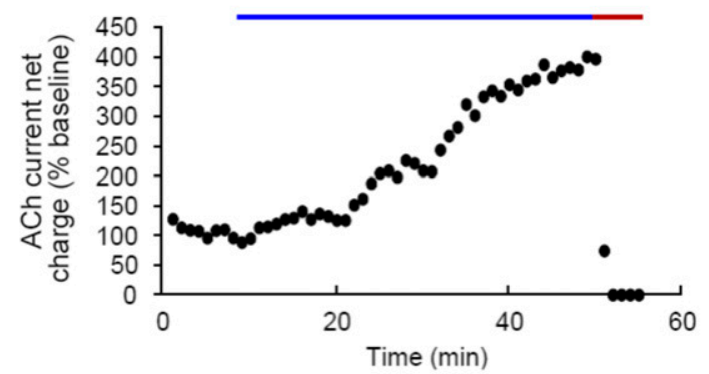

E

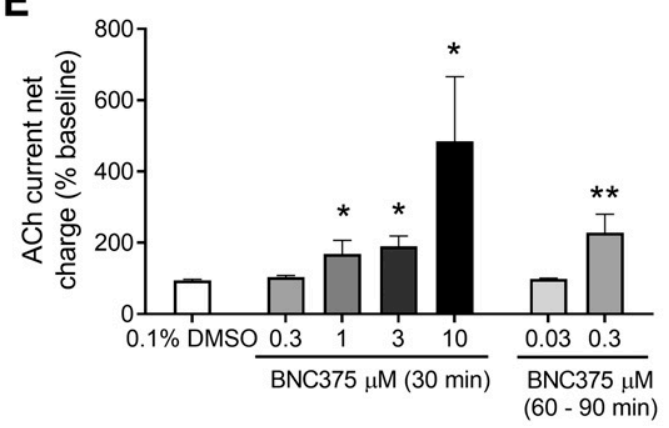

Fig. 3. Whole-cell patch-clamp recording in rat hippocampal interneurons evaluating the effect of BNC375 on ACh-evoked $\alpha 7$ current. (A) Representative traces of pharmacologically isolated $\alpha 7$ current evoked by brief application of $100 \mu \mathrm{M}$ ACh in stratum radiatum interneurons showing potentiation effect of $3 \mu \mathrm{M}$ BNC375 and inhibition of the current upon coapplication of $200 \mathrm{nM}$ MLA. (B and C) Example time plots showing the effects of $3 \mu \mathrm{M}$ BNC375 on normalized peak current amplitude (B) and net current charge (C). Application of $200 \mathrm{nM}$ MLA abolished the ACh-evoked current. (D and E) Dose-dependent effects of BNC375 on peak amplitude (D) and net current charge (E) of ACh-evoked $\alpha 7$ current in hippocampal interneurons. $* P<0.05 ; * *<0.01$ compared with the $0.1 \%$ DMSO group; $n=5-10$ /group. 
evaluated the impact of BNC375 on LTP in anesthetized Sprague-Dawley rats. Extracellular PS activity was recorded from the dentate gyrus of the hippocampus (Fig. 5). After 10 minutes of baseline recording, $\operatorname{BNC} 375(0.1,1$, or $10 \mathrm{mg} / \mathrm{kg}$, SC) was administrated 20 minutes prior to LTP induction. To examine if BNC375 has any effect on basal glutamatergic synaptic transmission in dentate gyrus granule cell layer, the PS amplitude at 10-20 minutes post-vehicle or BNC375 injection was normalized to the pretreatment baseline (Fig. 5, A and B). BNC375 alone has no effect on ongoing PS amplitude (Fig. 5C). LTP was induced by TBS of the perforant pathway with a bipolar electrode. Upon completion of LTP induction, responses were monitored for a further 60 minutes, and the PS amplitude at 50-60 minutes post LTP induction was normalized to the preinduction baseline (10 minutes before LTP induction). BNC375 enhanced LTP in a dosedependent manner (Fig. 5, B and D). At $10 \mathrm{mg} / \mathrm{kg}$, BNC375 significantly potentiated LTP to $126.8 \% \pm 4.7 \%$ of baseline ( $n=6, P<0.05$ compared with the vehicle group). Plasma concentrations of BNC375 at 80 minutes post-treatment were $0.024,0.28$, and $3.14 \mu \mathrm{M}$ at $0.1,1$, and $10 \mathrm{mg} / \mathrm{kg}$, respectively.

BNC375 Reverses a Scopolamine-Induced Deficit in Rat Novel Object Recognition. The impact of BNC375 on a scopolamine-induced deficit in rat novel object recognition was evaluated, and donepezil $(1.8 \mathrm{mg} / \mathrm{kg})$ served as a positive control (Fig. 6). Scopolamine (1 mg/kg) significantly impaired recognition $(44.8 \% \pm 5.2 \%, P<0.01)$ as compared with the vehicle-treated animals $(73.1 \% \pm 4.3 \%)$. BNC375 $(0.01-10 \mathrm{mg} / \mathrm{kg}$ by mouth) significantly reversed the scopolamine-induced deficit at all dose levels tested (Fig. 6A). The maximal effect of BNC375 at $10 \mathrm{mg} / \mathrm{kg}(69.9 \% \pm 6.5 \%$, Fig. $6 \mathrm{~A})$ is comparable to the improvement in performance observed with donepezil $(63.7 \% \pm$
$3.5 \%$, Fig. 6A). None of the treatments influenced exploration time or locomotion during either E1 or E2 (Fig. 6, B-E). Plasma concentrations of BNC375 at 60 minutes post-treatment were $0.0087,0.089,0.52$, and $4.42 \mu \mathrm{M}$ at $0.01,0.1,1$, and $10 \mathrm{mg} / \mathrm{kg}$ dose, respectively.

BNC375 Reverses a Scopolamine-Induced Deficit in Rhesus Monkey Object Retrieval Detour Task. The nonhuman primate ORD task is an assay dependent on executive function and attention and reliant on the prefrontal cortex. Performance in the ORD task can be impaired pharmacologically by scopolamine, and this deficit can be reversed by donepezil (Vardigan et al., 2015), which is the current standard of care for AD. To examine the impact of $\alpha 7$ PAM on cognitive function in the rhesus monkey, BNC375 was assessed for its ability to attenuate a scopolamine-induced cognitive impairment in the ORD task (Fig. 7). In animals not given scopolamine, $92.7 \% \pm 2.4 \%$ of the cognitively demanding difficult trials were completed correctly. Treatment with scopolamine resulted in a robust performance deficit, with only $53.6 \% \pm 2.8 \%$ of difficult trials completed correctly $(P<$ 0.001 compared with vehicle alone). BNC375 at 1 and $10 \mathrm{mg} / \mathrm{kg}$ (by mouth, 2-hour pretreatment time) significantly attenuated the scopolamine-induced deficit, increasing the performance to $68.2 \% \pm 5.4 \%$ and $75.5 \% \pm 3.7 \%$ in the difficult trials, respectively $(P<0.05$ compared with scopolamine alone, Fig. 7A). BNC375 at $0.1 \mathrm{mg} / \mathrm{kg}$ had no effect on scopolamine deficit $(54.6 \% \pm 5.9 \%, P=0.85$, Fig. 7A). BNC375 treatment did not impact easy trial performance (Fig. 7B). Total BNC375 plasma concentrations at 2 hours postdosing were $0.0048,0.028$, and $0.52 \mu \mathrm{M}$ at $0.1,1$, and $10 \mathrm{mg} / \mathrm{kg}$, respectively. Thus, BNC375 demonstrated efficacy in the ORD task over at least 18-fold range in exposures, with
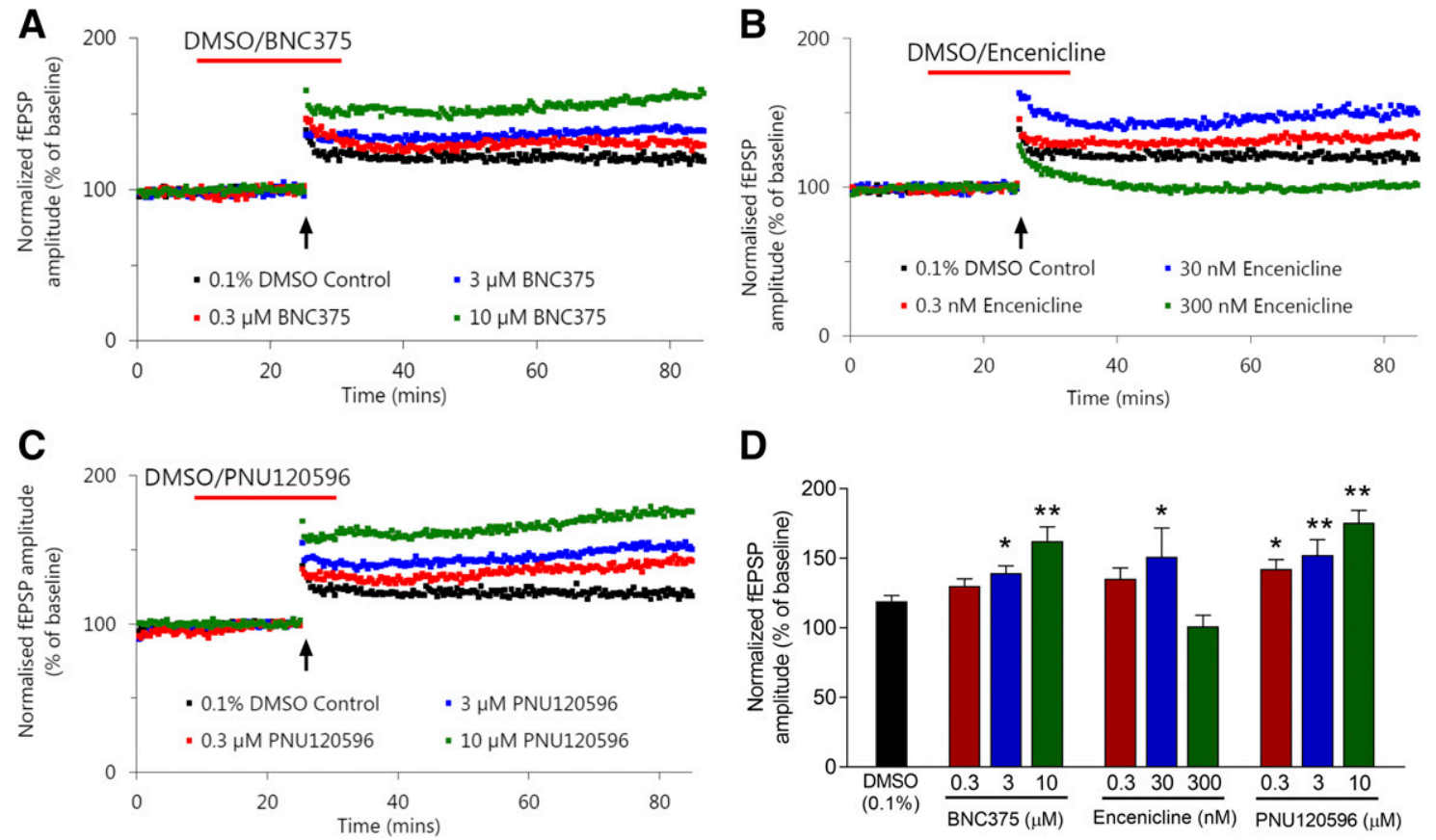

Fig. 4. fEPSP recording in rat hippocampal slices comparing the effect of BNC375, encenicline, and PNU120596 on LTP. (A-C) Time plots showing normalized fEPSP amplitude in the presence of 0.1\% DMSO and 0.3-10 $\mu \mathrm{M}$ BNC375 (A), 0.3-300 nM encenicline (B), and 0.3-10 $\mu \mathrm{M}$ PNU120596 (C). Red lines indicate the duration of 0.1\% DMSO or test compounds application. Arrows indicate the onset of TBS. (D) BNC375 and PNU120596 enhance LTP in a dose-dependent manner, whereas encenicline enhances LTP at low concentrations but attenuates LTP at a high concentration. $* P<0.05$; ** $P<0.01$ compared with the $0.1 \%$ DMSO group; $n=6$-8/group. 
A

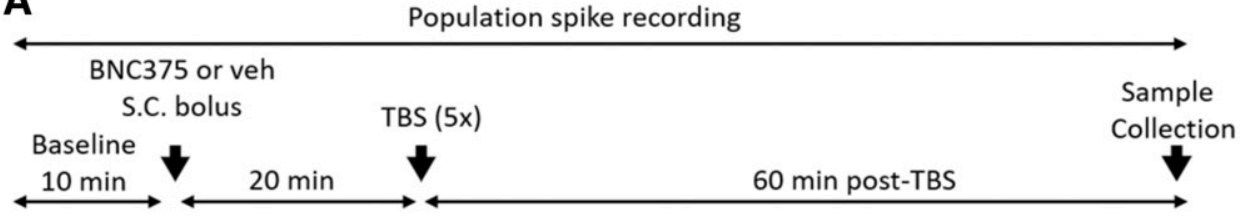

B
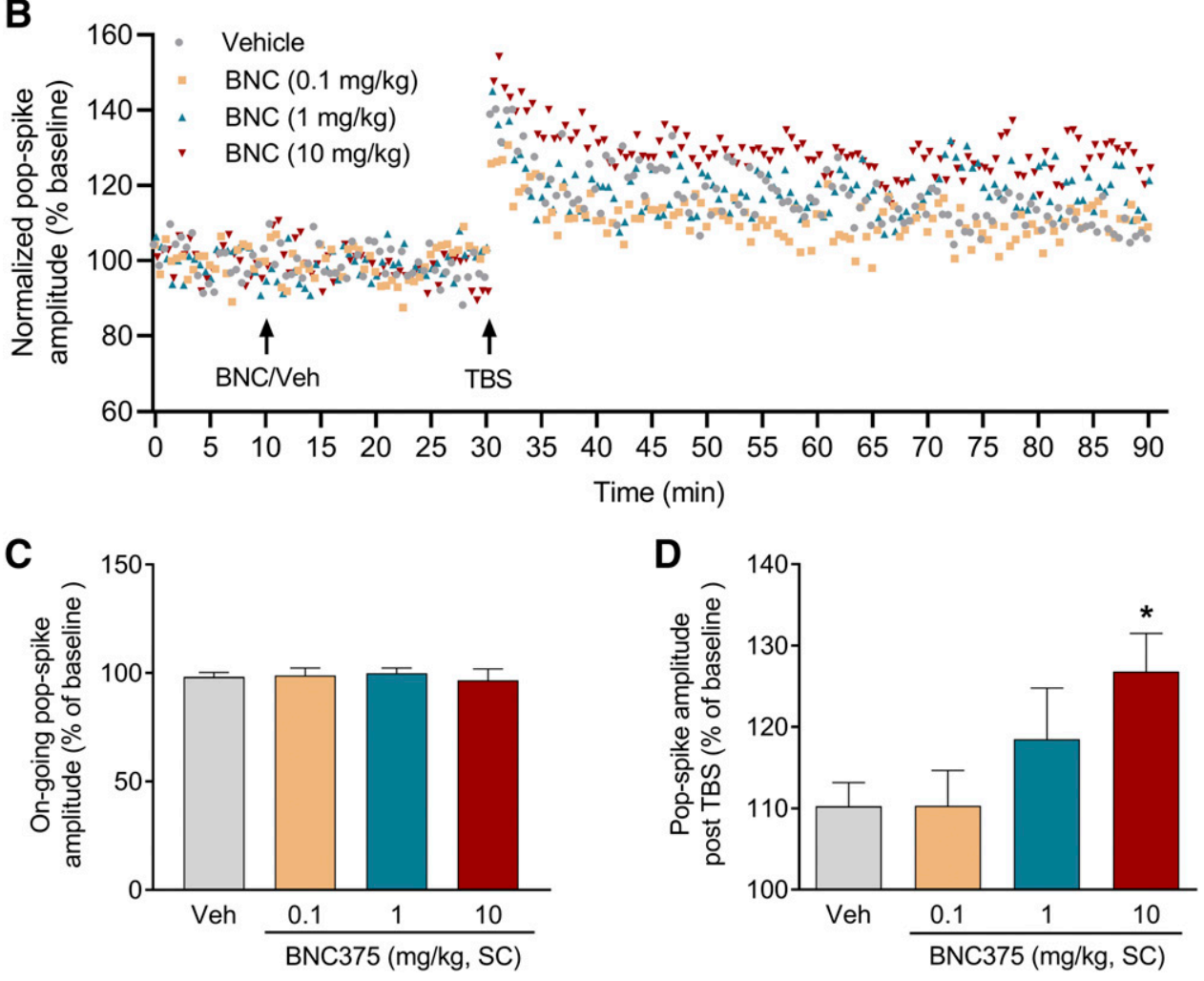

Fig. 5. Effect of BNC375 on TBS-induced LTP recorded from the rat dentate gyrus in vivo. (A) Experimental design illustrating the duration of population spike recording, the onset of BNC375 or vehicle administration, and TBS stimulation. (B) Time plots showing the effect of BNC375 on normalized population spike amplitude post-TBS stimulation. (C) BNC375 alone has no effect on on-going population spike amplitude prior to TBS. (D) BNC375 (0.1-10 mg/kg, SC) dose-dependently potentiated TBS-induced LTP recorded from the rat dentate gyrus in vivo. ${ }^{*} P<0.05$ compared with the vehicle group; $n=$ 6/group. no evidence of an inverted U-shaped dose-effect function. This range of efficacious exposures is larger than the approximately threefold range observed with donepezil in this assay, as higher doses of donepezil produce gastrointestinal adverse effects that prevent animals from performing (Vardigan et al., 2015).

BNC375 Improves Cognitive Function in Aged African Green Monkeys. Aged AGMs develop pathologic hallmarks of $\mathrm{AD}$, including plaques and neurofibrillary tangle-like structures (Cramer et al., 2018). In addition, aged AGMs demonstrate cognitive impairment that is ameliorated by donepezil, the standard care of AD (Cramer et al., 2018), suggesting that AGM may represent a novel translational animal model for AD. The effect of BNC375 in aged AGM was examined in the ORD task (Fig. 8). With vehicle treatment, $32.5 \% \pm 5.9 \%$ of the difficult trials were completed correctly by aged AGMs. BNC375 (3 mg/kg, IM) significantly ameliorated age-associated cognitive impairment, improving the performance to $58.8 \% \pm 6.9 \%(P<0.05$, Fig. $8 \mathrm{~A})$. Aged AGMs did not display cognitive impairment in easy trials, and BNC375 had no effect on easy trials (Fig. 8B). Plasma concentration of BNC375 at 30 minutes post-treatment was $1.04 \mu \mathrm{M}$ at $3 \mathrm{mg} / \mathrm{kg}$ dose.

BNC375 Enhances ${ }^{13} \mathrm{C}$ Enrichment in Brain Metabolites. Activation of $\alpha 7$ receptor has been shown to modulate the release of various neurotransmitters, including glutamate,
GABA, ACh, and dopamine. We applied ex vivo ${ }^{13} \mathrm{C} \mathrm{NMR}$ analysis to examine the effects of BNC375 on neurotransmitter cycling in the $\mathrm{mPFC}$ of the rat (Chowdhury et al., 2012). A subanesthetic dose of ketamine $(30 \mathrm{mg} / \mathrm{kg})$ was evaluated as a positive control, as similar treatments have been shown to produce robust effects on glutamate and GABA cycling (Castner et al., 2011). Consistent with the previous findings, ketamine at $30 \mathrm{mg} / \mathrm{kg}$ had a significant impact on the percent ${ }^{13} \mathrm{C}$ enrichment for all three metabolites in the $\mathrm{mPFC}$ region $(P<0.05$ for glutamate-C4, GABA-C2, and glutamine-C4) (Fig. 9). The effect of BNC375 was also observed in the mPFC for ${ }^{13} \mathrm{C}$ enrichment in glutamate-C4 $(P<0.05)$, GABA-C2 $(P<$ $0.05)$, and a trend of enrichment in glutamine-C4 $(P=0.07)$ (Fig. 9). These findings demonstrate that BNC375 acutely increases $\mathrm{mPFC}$ glutamate, glutamine, and GABA labeling from ${ }^{13} \mathrm{C}$ glucose, suggesting neurotransmitter cycling and release are modulated by BNC375 in vivo.

BNC375 Has No Effect on Cytotoxicity In Vitro. High permeability to $\mathrm{Ca}^{2+}$ is one of the unique functional properties of $\alpha 7 \mathrm{nAChR}$ (Bertrand et al., 1993; Séguéla et al., 1993). Excessive $\mathrm{Ca}^{2+}$ influx through $\alpha 7$ receptor may induce cytotoxicity, which has been observed in $\alpha 7$ expressing cell lines upon treatment with Type II $\alpha 7$ PAMs that reduced or abolished receptor desensitization ( $\mathrm{Ng}$ et al., 2007; Dinklo et al., 2011; Williams et al., 2012). To determine if Type I PAM 

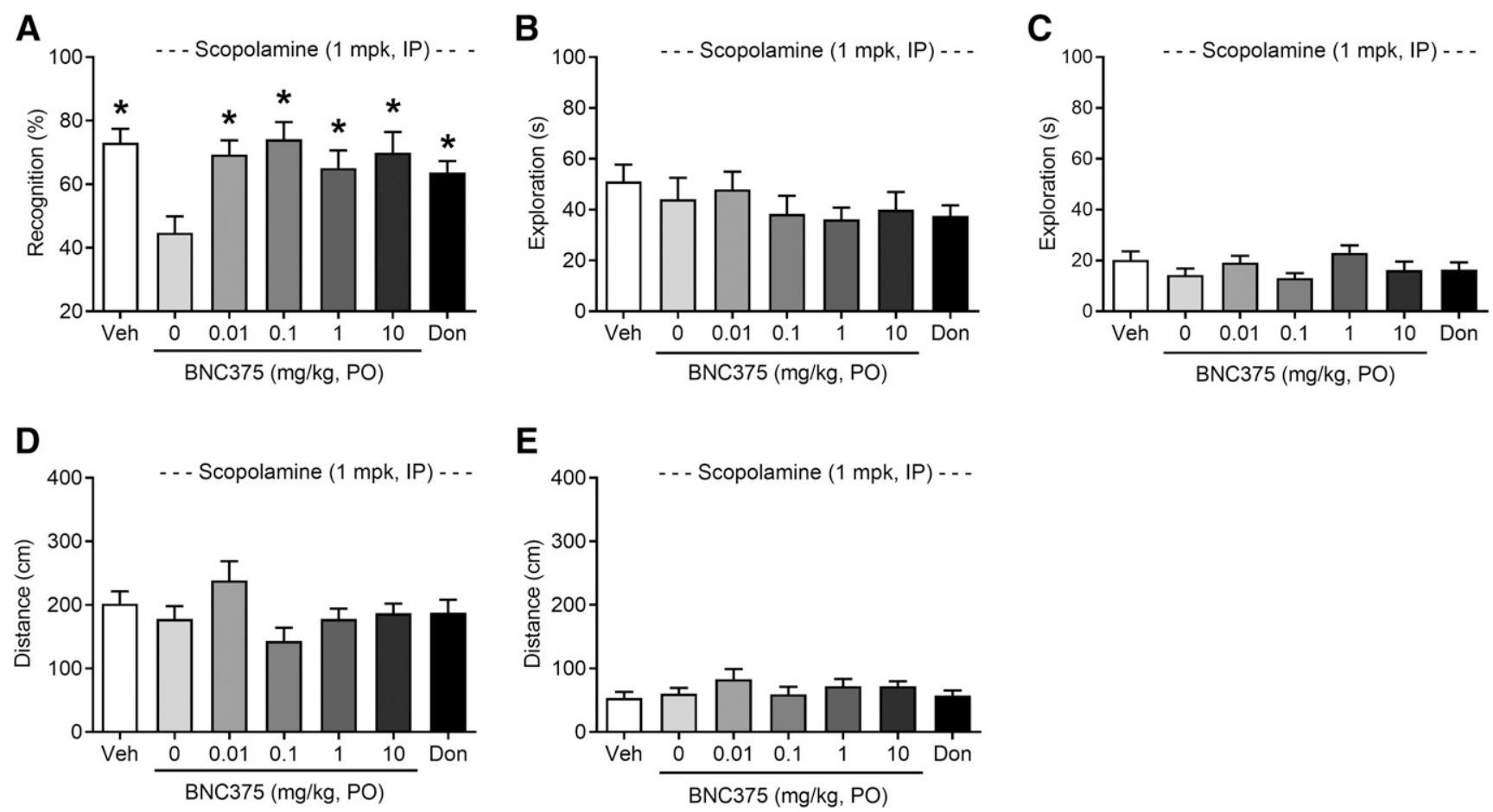

Fig. 6. Effect of BNC375 and donepezil (Don, $1.8 \mathrm{mg} / \mathrm{kg}$, IP) on a scopolamine-induced impairment in novel object recognition in rats. (A) Percentage exploration of the novel object during the second exposure. ${ }^{*} P<0.05$ compared with the vehicle-scopolamine group; $n=7-11 /$ group. (B and C) BNC375 and donepezil administration has no effect on object exploration time during the first exposure E1 (B) and the second exposure E2 (C). (D and E) BNC375 and donepezil treatment does not influence locomotion during E1 (D) and E2 (E).

BNC375 can induce cytotoxicity and differentiate BNC375 from Type II PAMs, we evaluated BNC375, PNU120596 (Type II PAM), and the enantiomer of BNC375 (Type II PAM) (Harvey et al., 2019) in a cytotoxicity assay with GH4C1 cells stably expressing rat $\alpha 7 \mathrm{nAChR}$ (Fig. 10). BNC375 up to $10 \mu \mathrm{M}$ had no effect on cell viability of the GH4C1 cells (Fig. 10A), whereas PNU120596 (Fig. 10B) and the enantiomer of BNC375 (Fig. 10C) dose-dependently reduced cell viability. Importantly, the cell deaths induced by the Type II PAMs were abolished by $\alpha 7$ antagonist MLA, suggesting the cytotoxicity was mediated by $\alpha 7 \mathrm{nAChR}$.

\section{Discussion}

Although PAMs of other Cys-loop receptors have been approved for clinical usage for decades, such as the $\mathrm{GABA}_{\mathrm{A}}$ receptor PAMs benzodiazepines, selective $\alpha 7$ PAMs have only recently been described in the literature $(\mathrm{Ng}$ et al., 2007;
Timmermann et al., 2007; Dinklo et al., 2011; Hurst et al., 2013; Sahdeo et al., 2014; Post-Munson et al., 2017). The current study provides an extensive pharmacological characterization of the novel Type I $\alpha 7$ PAM BNC375. In both HEK cells expressing recombinant human $\alpha 7 \mathrm{nAChRs}$ and hippocampal interneurons expressing native rat $\alpha 7 \mathrm{nAChRs}$, BNC375 potentiates ACh-evoked $\alpha 7$ current with little or no effect on receptor desensitization kinetics resembling the profile of Type I $\alpha 7$ PAMs (Ng et al., 2007; Timmermann et al., 2007). Additionally, in the absence of ACh, BNC375 has no effect on channel opening, suggesting lack of endogenous agonist activity consistent with the profile of other $\alpha 7$ PAMs (Ng et al., 2007; Hurst et al., 2013).

Evaluating the procognitive effect of BNC375 in NHPs may help us better understand the probability of success in clinical studies because of the unique translational value of NHPs (Capitanio and Emborg, 2008; Nelson and Winslow, 2009; Shively and Clarkson, 2009; Cramer et al., 2018). This may be
A

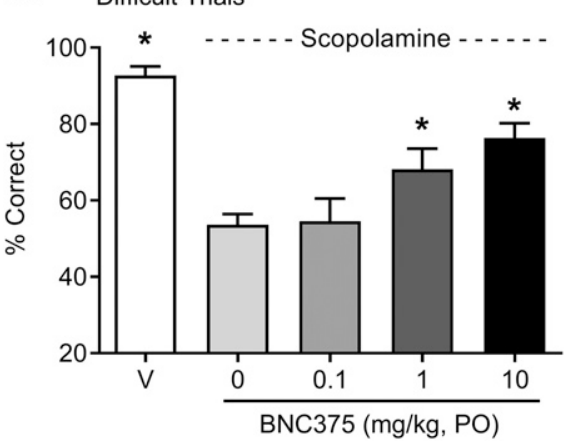

B Easy Trials

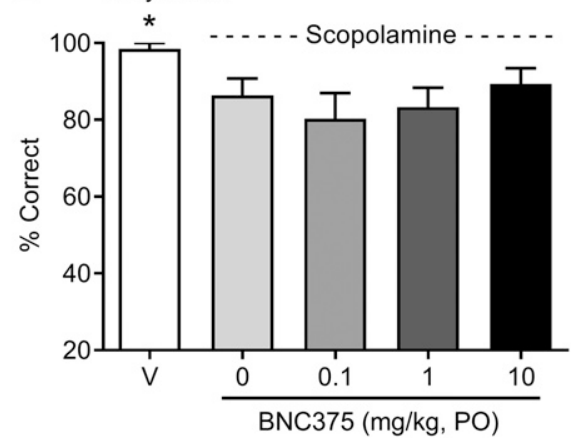

Fig. 7. Effect of BNC375 on scopolamineinduced impairment in an object retrieval detour task in rhesus monkey. (A) BNC375 dosedependently reverses scopolamine-induced impairment in the difficult trials. (B) BNC375 has no effect on easy trials. $* P<0.05$ compared with the scopolamine alone group; $n=11$ /group. 

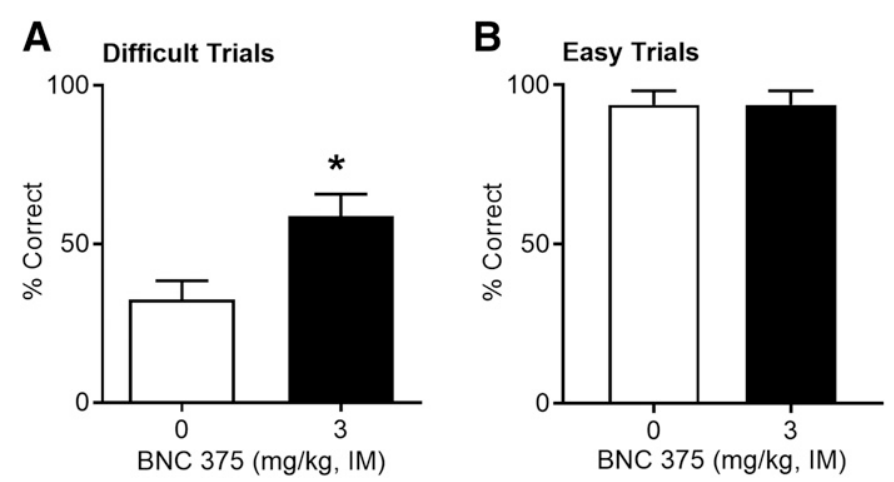

Fig. 8. Effect of BNC375 on an object retrieval detour task in aged African green monkey. BNC375 at $3 \mathrm{mg} / \mathrm{kg}$ significantly improves performance in the difficult trials (A) but not in the easy trials (B). ${ }^{*} P<0.05 ; n=8$ /group.

particularly important for ligands activating $\alpha 7 \mathrm{nAChRs}$ given the difference in the expression pattern of $\alpha 7 \mathrm{nAChRs}$ in rodents as compared with higher species (Cimino et al., 1992; Breese et al., 1997; Spurden et al., 1997). For example, $\alpha 7 \mathrm{nAChRs}$ have been identified in reticular nuclei of the thalamus in cynomolgus macaques (Cimino et al., 1992) and in human brain (Breese et al., 1997; Spurden et al., 1997), whereas little [125I]- $\alpha$ BTX binding has been observed in thalamic nuclei of the rat (Clarke et al., 1985; Tribollet et al., 2004). In contrast to reticular nuclei, high expression levels of $\alpha 7 \mathrm{nAChRs}$ in hippocampus have been detected across rodents, NHPs, and human (Séguéla et al., 1993; Breese et al., 1997; Whiteaker et al., 1999). In addition, activation of $\alpha 7 \mathrm{nAChR}$ in rat hippocampus has been shown to enhance LTP both ex vivo and in vivo, indicating that BNC375 may demonstrate procognitive effects in NHPs. In the present studies, we characterized BNC375 in the ORD assay in scopolamine-impaired rhesus monkeys. To our knowledge, this is the first time that an $\alpha 7$ Type I PAM has been evaluated in NHPs. In rhesus monkeys, BNC375 dosedependently reversed the scopolamine-induced cognitive impairment over at least an 18-fold range in exposures. In contrast, $\alpha 7$ agonists, such as GTS-21, encenicline, and AZD0328, have frequently demonstrated sharp inverted U-shaped dose-effect function in NHP cognition assays
(Castner et al., 2011; Cannon et al., 2013; Weed et al., 2017). For example, GTS-21 reversed ketamine-induced deficit in rhesus ORD assay only at $0.03 \mathrm{mg} / \mathrm{kg}$ but not at 0.01 or $0.1 \mathrm{mg} / \mathrm{kg}$ (Cannon et al., 2013). In a rhesus paired associated learning task, encenicline was evaluated at six doses ranging from 0.003 to $1 \mathrm{mg} / \mathrm{kg}$, but a significant reversal of the scopolamine impairment was only observed at $0.01 \mathrm{mg} / \mathrm{kg}$ (Weed et al., 2017). These findings suggest that $\alpha 7$ PAMs may demonstrate efficacy over a much wider range of exposures as compared with the agonists.

In addition to the scopolamine-impaired rhesus monkeys, BNC375 was also evaluated in aged AGMs, a model that may represent an improved preclinical model of naturally occurring $\mathrm{AD}$. For example, the transcriptome profile obtained from the prefrontal cortex of aged AGMs aligns with gene expression changes observed in $\mathrm{AD}$ brain (Cramer et al., 2018). Histologically, aged AGMs display age-related increases in $\mathrm{A} \beta$ plaques, and some aged animals also show evidence of naturally occurring tauopathy (Kalinin et al., 2013; Cramer et al., 2018). Furthermore, AGMs exhibit age-related cognitive impairment in ORD assay, which can be ameliorated by the standard of $\mathrm{AD}$ care, donepezil (Cramer et al., 2018). The ORD task relies heavily on the function of the prefrontal cortex (Eddins et al., 2014; Vardigan et al., 2015), which is where the transcriptome analysis was performed and where the histologic changes were observed in AGMs. Importantly, $\alpha 7$ nAChRs have been shown to reside on cholinergic and dopaminergic nerve terminals in the prefrontal cortex (Duffy et al., 2009), and in vivo microdialysis studies have reported elevated ACh and dopamine concentrations in prefrontal cortex upon $\alpha 7 \mathrm{nAChR}$ activation (Biton et al., 2007; Tietje et al., 2008). In the current study, aged AGMs demonstrated cognitive impairment in the ORD assay, and BNC375 at $3 \mathrm{mg} / \mathrm{kg}$ significantly reversed age-related impairment to the same extent as donepezil (Cramer et al., 2018).

Ex vivo ${ }^{13} \mathrm{C}-\mathrm{NMR}$ studies were performed here to examine the effects of BNC375 on amino acid neurotransmitter cycling and neuronal energy metabolism in rat prefrontal cortex. In this assay, ${ }^{13} \mathrm{C}$-labeled glucose is metabolized mainly in the neuronal tricarboxylic cycle and is incorporated into neuronal glutamate and GABA, which are released at the presynaptic terminals and recycled by astrocytes, followed by conversion to
A

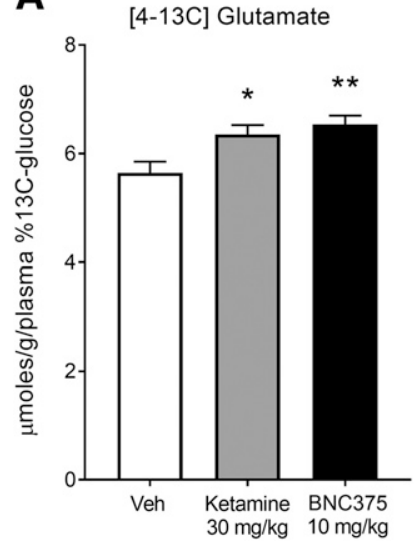

B

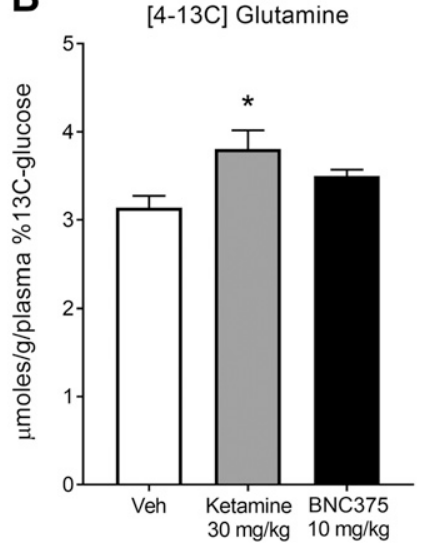

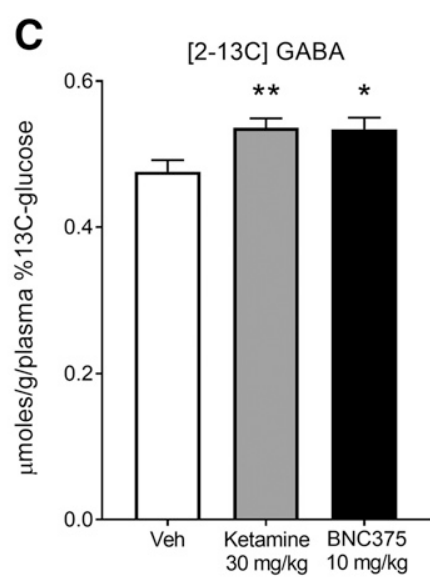

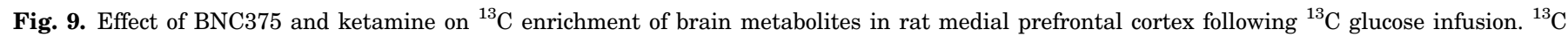

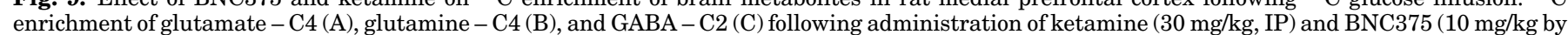
mouth). $* P<0.05$; $* * P<0.01$ compared with the vehicle group; $n=12$ /group. 

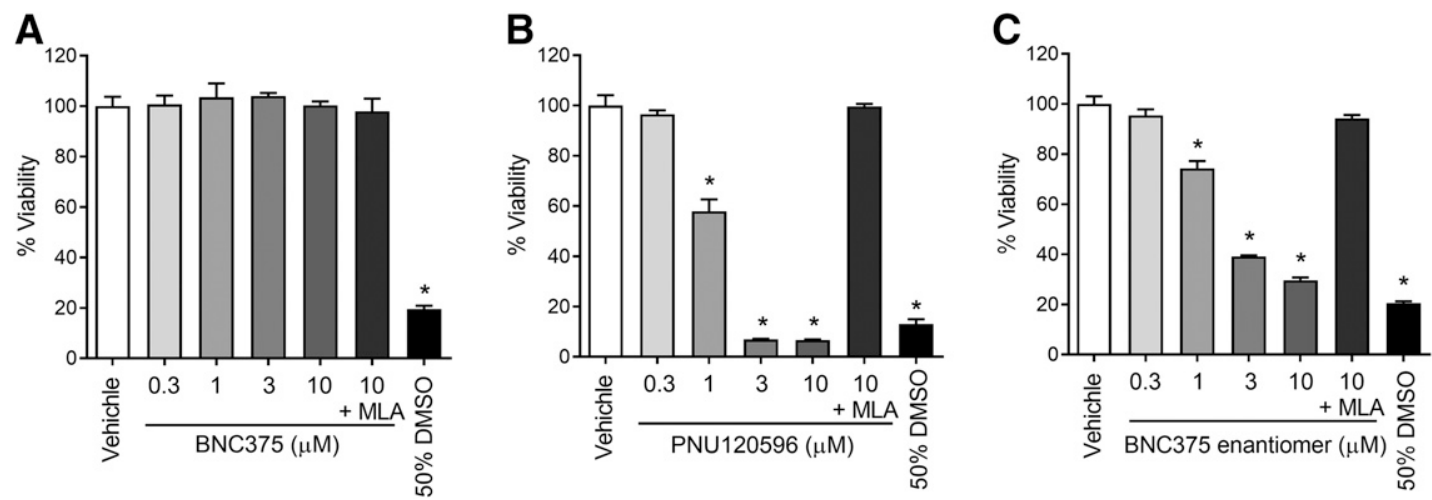

Fig. 10. Cytotoxicity assay comparing the effect of Type I and Type II $\alpha 7$ PAMs on cell viability in vitro. GH4C 1 cells expressing rat $\alpha 7 \mathrm{nAChR}$ were incubated with BNC375 (A), PNU120596 (B), the enantiomer of BNC375 (C), or positive control 50\% DMSO for 2 hours. Cytotoxicity was determined by XTT-based assay. PNU120596 and the enantiomer of BNC375, but not BNC375, dose-dependently reduced cell viability. Application of MLA (10 $\mu$ M) abolished the cytotoxicity induced by PNU120596 and the enantiomer of BNC375. ${ }^{*} P<0.05$ compared with the vehicle group, $n=3$ to 4 /group.

glutamine (Chowdhury et al., 2012). Therefore, the NMR analysis with ${ }^{13} \mathrm{C}$-labeled glucose can provide information on glutamate and GABA neurotransmitter cycling and neuronal metabolism. This technique has been successfully applied to characterize the physiologic process underlying ketamine's rapid antidepressant-like effect in preclinical models and in human (Chowdhury et al., 2012; Abdallah et al., 2018). Here we show that BNC375, at an efficacious dose in the animal behavior studies, acutely increased ${ }^{13} \mathrm{C}$ enrichments in $\mathrm{mPFC}$ glutamate, glutamine, and GABA from ${ }^{13} \mathrm{C}$-glucose, indicating neurotransmitter cycling is enhanced by BNC375. These findings are consistent with previous in vivo microdialysis studies showing activation of $\alpha 7 \mathrm{nAChR}$ is associated with increased neurotransmitter release in various brain regions, including prefrontal cortex (Biton et al., 2007; Tietje et al., 2008; Livingstone et al., 2009). Over the last decade, significant progress has been made toward developing novel $\alpha 7$ positron emission tomography tracers that bind to the orthosteric binding site (Chalon et al., 2015), such as [18F]ASEM, which has advanced to clinic to determine the target engagement of $\alpha 7$ agonists (Wong et al., 2014, 2018). However, developing an $\alpha 7$ positron emission tomography tracer targeting the allosteric binding site has been a challenge. The ${ }^{13} \mathrm{C}-\mathrm{NMR}$ approach could be extremely useful in demonstrating in vivo target modulation by $\alpha 7$ PAMs as well as the pharmacokinetic and pharmacodynamic relationship in animal models and clinical studies.

$\alpha 7$ nAChR is highly permeable to $\mathrm{Ca}^{2+}$ (Bertrand et al., 1993; Delbono et al., 1997), which is critical for its $\mathrm{Ca}^{2+}$. dependent function under physiologic conditions (Role and Berg, 1996; Albuquerque et al., 1997). However, accumulating evidence suggests that excessive $\mathrm{Ca}^{2+}$ influx through $\alpha 7$ receptor may perturb intracellular $\mathrm{Ca}^{2+}$ homeostasis and induce cytotoxicity. This has been demonstrated in a mouse model expressing $\alpha 7 \mathrm{nAChR}$ with "gain of function" mutation (L250T) that reduced receptor desensitization (Orr-Urtreger et al., 2000). In the homozygous mice, the mutation is associated with extensive neuronal cell death throughout cortex and is lethal at birth (Orr-Urtreger et al., 2000). In addition, Type II PAMs, but not Type I PAMs, have been shown to induce cytotoxicity in multiple cell lines expressing $\alpha 7$ receptor (Ng et al., 2007; Dinklo et al., 2011; Williams et al., 2012). The current study confirmed the previous finding that
Type II PAM PNU120596 can induce cell death in GH4C1 cells expressing $\alpha 7$ receptor. In addition, we compared BNC375 (Type I PAM) and its enantiomer (Type II PAM) (Harvey et al., 2019 ) in the cytotoxicity assay. The only difference between the two molecules is the stereochemistry around the central cyclopropyl ring, which provides us an excellent tool to differentiate Type I versus Type II PAMs with regard to the impact on cell viability. As expected, the enantiomer of BNC375 induced cell death in a dose-dependent manner, whereas BNC375 has no effect on cell viability. Although the cytotoxicity associated with Type II PAMs needs to be further evaluated in in vivo conditions, the current findings suggest that chronic treatment of Type II PAMs may put neurons with high $\alpha 7 \mathrm{nAChR}$ expression levels at risk in clinical settings.

We noticed that the in vitro potency of BNC375 is in the low micromolar range $\left(\mathrm{EC}_{50}=2.64 \mu \mathrm{M}\right)$, whereas $\mathrm{BNC} 375$ is active in vivo at much lower exposures. For example, the minimum effective dose of BNC375 in the rat novel object recognition assay is $0.01 \mathrm{mg} / \mathrm{kg}$, which is associated with $0.0087 \mu \mathrm{M}$ plasma concentration. In addition, BNC375 reversed scopolamine-induced deficit at $0.028 \mu \mathrm{M}$ plasma exposure in the rhesus ORD assay. The dissociation between in vitro and in vivo potency has been observed with many other $\alpha 7$ PAMs. In fact, the in vitro potency of most $\alpha 7$ PAMs, such as NS1738, AVL-3288, JNJ-193942, A-867744, and RO5126946, are in the low micromolar range, whereas these compounds produce efficacy in vivo at exposures that are several orders of magnitude lower ( $\mathrm{Ng}$ et al., 2007; Timmermann et al., 2007; Malysz et al., 2009; Dinklo et al., 2011; Sahdeo et al., 2014). For example, JNJ-1930942 was reported to potentiate $\alpha 7$ current in vitro with an $\mathrm{EC}_{50}$ of $1.9 \mu \mathrm{M}$. In contrast, JNJ-1930942 improves sensory gating in $\mathrm{DBA} / 2$ mice at $1.3 \mathrm{nM}$ free brain exposure (Dinklo et al., 2011). Exactly how $\alpha 7$ PAMs produce efficacy in vivo with such low exposure is not fully understood, but this observation indicates very low levels of target engagement are sufficient to produce robust pharmacodynamic effects, which is consistent across models and species. Another possible explanation is that the potential difference in the concentrations of ACh in vitro versus in vivo may influence the potency and efficacy of BNC375. In the current study, the in vitro potency of BNC375 was determined with $\mathrm{EC}_{20}$ concentration of $\mathrm{ACh}$, whereas the brain concentration of $\mathrm{ACh}$ at the $\alpha 7$ receptors is largely 
unknown. We have observed that the potency and efficacy of Type I PAMs can be quite sensitive to ACh concentration.

In summary, this study characterizes the in vitro and in vivo pharmacological profiles of BNC375, a novel Type I PAM of the $\alpha 7 \mathrm{nAChR}$. BNC375 potentiates ACh-induced $\alpha 7$ current in both cell lines recombinantly expressing human wild-type $\alpha 7 \mathrm{nAChRs}$ and in rat hippocampus interneurons. In hippocampal slices as well as hippocampal recordings in vivo, BNC375 enhances LTP, suggesting a potential benefit to cognitive processes. In vivo, BNC375 improves cognitive function in both rodents and NHPs, including the AGM model, which is associated with naturally occurring $\mathrm{AD}$ pathology. Finally, BNC375 increases neurotransmitter cycling as demonstrated by the ${ }^{13} \mathrm{C}-\mathrm{NMR}$ analysis, which could serve as a translational biomarker to understand target modulation in patients. These findings provide a rationale for appropriately testing a selective $\alpha 7$ Type I PAM to improve cognitive function in patients with Alzheimer disease.

\section{Authorship Contributions}

Participated in research design: Wang, Daley, Lange, Miller, Harvey, Grishin, Coles, O'Connor, Thomson, Duffy, Bell, Uslaner.

Conducted experiments: Wang, Daley, Gakhar, Lange, Vardigan, Pearson, Zhou, Warren, Miller, Belden, Grishin, Coles.

Performed data analysis: Wang, Daley, Gakhar, Lange, Vardigan, Pearson, Zhou, Warren, Miller, Grishin, Coles.

Wrote or contributed to the writing of the manuscript: Wang, Daley, Miller, Warren, Coles, O’Connor, Thomson, Duffy, Bell, Uslaner.

\section{References}

Abdallah CG, De Feyter HM, Averill LA, Jiang L, Averill CL, Chowdhury GMI, Purohit P, de Graaf RA, Esterlis I, Juchem C, et al.(2018) The effects of ketamine on prefrontal glutamate neurotransmission in healthy and depressed subjects. Neuropsychopharmacology 43:2154-2160.

Albuquerque EX, Alkondon M, Pereira EF, Castro NG, Schrattenholz A, Barbosa CT, Bonfante-Cabarcas R, Aracava Y, Eisenberg HM, and Maelicke A(1997) Properties of neuronal nicotinic acetylcholine receptors: pharmacological characterization and modulation of synaptic function. J Pharmacol Exp Ther 280:1117-1136.

Bertrand D, Galzi JL, Devillers-Thiéry A, Bertrand S, and Changeux JP(1993) Mutations at two distinct sites within the channel domain M2 alter calcium permeability of neuronal alpha 7 nicotinic receptor. Proc Natl Acad Sci USA 90: 6971-6975.

Bertrand D, Lee CH, Flood D, Marger F, and Donnelly-Roberts D(2015) Therapeutic potential of $\alpha 7$ nicotinic acetylcholine receptors. Pharmacol Rev 67:1025-1073.

Biton B, Bergis OE, Galli F, Nedelec A, Lochead AW, Jegham S, Godet D, Lanneau C, Santamaria R, Chesney F, et al.(2007) SSR180711, a novel selective alpha7 nicotinic receptor partial agonist: (1) binding and functional profile. Neuropsychopharmacology 32:1-16.

Breese CR, Adams C, Logel J, Drebing C, Rollins Y, Barnhart M, Sullivan B, Demasters BK, Freedman R, and Leonard S(1997) Comparison of the regional expression of nicotinic acetylcholine receptor alpha7 mRNA and [125I]-alphabungarotoxin binding in human postmortem brain. J Comp Neurol 387:385-398.

Cannon CE, Puri V, Vivian JA, Egbertson MS, Eddins D, and Uslaner JM(2013) The nicotinic $\alpha 7$ receptor agonist GTS-21 improves cognitive performance in ketamine impaired rhesus monkeys. Neuropharmacology 64:191-196.

Capitanio JP and Emborg ME(2008) Contributions of non-human primates to neuroscience research. Lancet 371:1126-1135.

Castner SA, Smagin GN, Piser TM, Wang Y, Smith JS, Christian EP, Mrzljak L, and Williams GV(2011) Immediate and sustained improvements in working memory after selective stimulation of $\alpha 7$ nicotinic acetylcholine receptors. Biol Psychiatry 69:12-18.

Chalon S, Vercouillie J, Guilloteau D, Suzenet F, and Routier S(2015) PET tracers for imaging brain $\alpha 7$ nicotinic receptors: an update. Chem Commun (Camb) 51: 14826-14831.

Chowdhury GM, Behar KL, Cho W, Thomas MA, Rothman DL, and Sanacora $\mathrm{G}(2012){ }^{1} \mathrm{H}-\left[{ }^{13} \mathrm{C}\right]$-nuclear magnetic resonance spectroscopy measures of ketamine's effect on amino acid neurotransmitter metabolism. Biol Psychiatry 71:1022-1025.

Chowdhury GM, Zhang J, Thomas M, Banasr M, Ma X, Pittman B, Bristow L, Schaeffer E, Duman RS, Rothman DL, et al.(2017) Transiently increased glutamate cycling in rat PFC is associated with rapid onset of antidepressant-like effects. Mol Psychiatry 22:120-126.

Cimino M, Marini P, Fornasari D, Cattabeni F, and Clementi F(1992) Distribution of nicotinic receptors in cynomolgus monkey brain and ganglia: localization of alpha 3 subunit mRNA, alpha-bungarotoxin and nicotine binding sites. Neuroscience 51: 77-86.

Clarke PB, Schwartz RD, Paul SM, Pert CB, and Pert A(1985) Nicotinic binding in rat brain: autoradiographic comparison of $[3 \mathrm{H}]$ acetylcholine, $[3 \mathrm{H}]$ nicotine, and [125I]-alpha-bungarotoxin. J Neurosci 5:1307-1315.
Cramer PE, Gentzel RC, Tanis KQ, Vardigan J, Wang Y, Connolly B, Manfre P, Lodge K, Renger JJ, Zerbinatti C, et al.(2018) Aging African green monkeys manifest transcriptional, pathological, and cognitive hallmarks of human Alzheimer's disease. Neurobiol Aging 64:92-106.

Deardorff WJ, Shobassy A, and Grossberg GT(2015) Safety and clinical effects of EVP-6124 in subjects with Alzheimer's disease currently or previously receiving an acetylcholinesterase inhibitor medication. Expert Rev Neurother 15:7-17.

Delbono O, Gopalakrishnan M, Renganathan M, Monteggia LM, Messi ML, and Sullivan JP(1997) Activation of the recombinant human alpha 7 nicotinic acetylcholine receptor significantly raises intracellular free calcium. $J$ Pharmacol Exp Ther 280:428-438.

Dinklo T, Shaban H, Thuring JW, Lavreysen H, Stevens KE, Zheng L, Mackie C, Grantham C, Vandenberk I, Meulders G, et al.(2011) Characterization of 2-[[4fluoro-3-(trifluoromethyl)phenyl]amino]-4-(4-pyridinyl)-5-thiazolemethanol (JNJ1930942), a novel positive allosteric modulator of the alpha7 nicotinic acetylcholine receptor. J Pharmacol Exp Ther 336:560-574.

Duffy AM, Zhou P, Milner TA, and Pickel VM(2009) Spatial and intracellular relationships between the alpha7 nicotinic acetylcholine receptor and the vesicular acetylcholine transporter in the prefrontal cortex of rat and mouse. Neuroscience 161:1091-1103.

Eddins D, Hamill TG, Puri V, Cannon CE, Vivian JA, Sanabria-Bohórquez SM, Cook JJ, Morrow JA, Thomson F, and Uslaner JM(2014) The relationship between glycine transporter 1 occupancy and the effects of the glycine transporter 1 inhibitor RG1678 or ORG25935 on object retrieval performance in scopolamine impaired rhesus monkey. Psychopharmacology (Berl) 231:511-519.

Freedman R, Hall M, Adler LE, and Leonard S(1995) Evidence in postmortem brain tissue for decreased numbers of hippocampal nicotinic receptors in schizophrenia. Biol Psychiatry 38:22-33.

Gee KW, Olincy A, Kanner R, Johnson L, Hogenkamp D, Harris J, Tran M, Edmonds SA, Sauer W, Yoshimura R, et al.(2017) First in human trial of a type I positive allosteric modulator of alpha7-nicotinic acetylcholine receptors: pharmacokinetics, safety, and evidence for neurocognitive effect of AVL-3288. J Psychopharmacol 31: 434-441.

Guan ZZ, Zhang X, Ravid R, and Nordberg A(2000) Decreased protein levels of nicotinic receptor subunits in the hippocampus and temporal cortex of patients with Alzheimer's disease. J Neurochem 74:237-243.

Han ZY, Zoli M, Cardona A, Bourgeois JP, Changeux JP, and Le Novère N(2003) Localization of $[3 \mathrm{H}]$ nicotine, $[3 \mathrm{H}]$ cytisine, [3H]epibatidine, and [125I]alphabungarotoxin binding sites in the brain of Macaca mulatta. J Comp Neurol 461: 49-60.

Harvey AJ, Avery TD, Schaeffer L, Joseph C, Huff BC, Singh R, Morice C, Giethlen B, Grishin AA, Coles CJ, et al.(2019) Discovery of BNC375, a potent, selective, and orally available type I positive allosteric modulator of $\alpha 7 \mathrm{nAChRs}$. ACS Med Chem Lett 10:754-760.

Huang M, Felix AR, Kwon S, Lowe D, Wallace T, Santarelli L, and Meltzer HY(2014) The alpha-7 nicotinic receptor partial agonist/5-HT3 antagonist RG3487 enhances cortical and hippocampal dopamine and acetylcholine release. Psychopharmacology (Berl) 231:2199-2210.

Hurst R, Rollema H, and Bertrand D(2013) Nicotinic acetylcholine receptors: from basic science to therapeutics. Pharmacol Ther 137:22-54.

Kadir A, Almkvist O, Wall A, Långström B, and Nordberg A(2006) PET imaging of cortical 11C-nicotine binding correlates with the cognitive function of attention in Alzheimer's disease. Psychopharmacology (Berl) 188:509-520.

Kalinin S, Willard SL, Shively CA, Kaplan JR, Register TC, Jorgensen MJ, Polak PE, Rubinstein I, and Feinstein DL(2013) Development of amyloid burden in African Green monkeys. Neurobiol Aging 34:2361-2369.

Keller JJ, Keller AB, Bowers BJ, and Wehner JM(2005) Performance of alpha7 nicotinic receptor null mutants is impaired in appetitive learning measured in a signaled nose poke task. Behav Brain Res 162:143-152.

Koranda JL, Cone JJ, McGehee DS, Roitman MF, Beeler JA, and Zhuang X(2014) Nicotinic receptors regulate the dynamic range of dopamine release in vivo. J Neurophysiol 111:103-111.

Le Pichon JB, Yu S, Kibiryeva N, Graf WD, and Bittel DC(2013) Genome-wide gene expression in a patient with $15 q 13.3$ homozygous microdeletion syndrome. Eur J Hum Genet 21:1093-1099.

Livingstone PD, Srinivasan J, Kew JN, Dawson LA, Gotti C, Moretti M, Shoaib M, and Wonnacott S(2009) alpha7 and non-alpha7 nicotinic acetylcholine receptors modulate dopamine release in vitro and in vivo in the rat prefrontal cortex. Eur J Neurosci 29:539-550.

Malysz J, Grønlien JH, Anderson DJ, Håkerud M, Thorin-Hagene K, Ween H, Wetterstrand C, Briggs CA, Faghih R, Bunnelle WH, et al.(2009) In vitro pharmacological characterization of a novel allosteric modulator of alpha 7 neuronal acetylcholine receptor, 4-(5-(4-chlorophenyl)-2-methyl-3-propionyl-1H-pyrrol-1-yl) benzenesulfonamide (A-867744), exhibiting unique pharmacological profile. J Pharmacol Exp Ther 330:257-267.

Nelson EE and Winslow JT(2009) Non-human primates: model animals for developmental psychopathology. Neuropsychopharmacology 34:90-105.

Ng HJ, Whittemore ER, Tran MB, Hogenkamp DJ, Broide RS, Johnstone TB, Zheng L, Stevens KE, and Gee KW(2007) Nootropic alpha7 nicotinic receptor allosteric modulator derived from GABAA receptor modulators. Proc Natl Acad Sci USA 104: 8059-8064.

Orr-Urtreger A, Broide RS, Kasten MR, Dang H, Dani JA, Beaudet AL, and Patrick JW(2000) Mice homozygous for the L250T mutation in the alpha7 nicotinic acetylcholine receptor show increased neuronal apoptosis and die within 1 day of birth. J Neurochem 74:2154-2166.

Perkins KA, Roy Chengappa KN, Karelitz JL, Boldry MC, Michael V, Herb T, Gannon J, Brar J, Ford L, Rassnick S, et al.(2018) Initial cross-over test of a positive allosteric modulator of alpha-7 nicotinic receptors to aid cessation in smokers with or without schizophrenia. Neuropsychopharmacology 43: 1334-1342. 
Pichat P, Bergis OE, Terranova JP, Urani A, Duarte C, Santucci V, Gueudet C, Voltz C, Steinberg R, Stemmelin J, et al.(2007) SSR180711, a novel selective alpha7 nicotinic receptor partial agonist: (II) efficacy in experimental models predictive of activity against cognitive symptoms of schizophrenia. Neuropsychopharmacology 32:17-34.

Post-Munson DJ, Pieschl RL, Molski TF, Graef JD, Hendricson AW, Knox RJ, McDonald IM, Olson RE, Macor JE, Weed MR, et al.(2017) B-973, a novel piperazine positive allosteric modulator of the $\alpha 7$ nicotinic acetylcholine receptor. Eur J Pharmacol 799:16-25.

Prickaerts J, van Goethem NP, Chesworth R, Shapiro G, Boess FG, Methfessel C, Reneerkens OA, Flood DG, Hilt D, Gawryl M, et al.(2012) EVP-6124, a novel and selective $\alpha 7$ nicotinic acetylcholine receptor partial agonist, improves memory performance by potentiating the acetylcholine response of $\alpha 7$ nicotinic acetylcholine receptors. Neuropharmacology 62:1099-1110.

Rezvani AH, Kholdebarin E, Brucato FH, Callahan PM, Lowe DA, and Levin ED(2009) Effect of R3487/MEM3454, a novel nicotinic alpha7 receptor partial agonist and 5-HT3 antagonist on sustained attention in rats. Prog Neuropsychopharmacol Biol Psychiatry 33:269-275.

Risa O, Melø TM, and Sonnewald U(2009) Quantification of amounts and (13)C content of metabolites in brain tissue using high- resolution magic angle spinning (13)C NMR spectroscopy. NMR Biomed 22:266-271.

Role LW and Berg DK(1996) Nicotinic receptors in the development and modulation of CNS synapses. Neuron 16:1077-1085.

Sahdeo S, Wallace T, Hirakawa R, Knoflach F, Bertrand D, Maag H, Misner D, Tombaugh GC, Santarelli L, Brameld K, et al.(2014) Characterization of RO5126946, a Novel $\alpha 7$ nicotinic acetylcholine receptor-positive allosteric modulator. J Pharmacol Exp Ther 350:455-468.

Séguéla P, Wadiche J, Dineley-Miller K, Dani JA, and Patrick JW(1993) Molecular cloning, functional properties, and distribution of rat brain alpha 7: a nicotinic cation channel highly permeable to calcium. J Neurosci 13:596-604.

Sharp AJ, Mefford HC, Li K, Baker C, Skinner C, Stevenson RE, Schroer RJ, Novara F, De Gregori M, Ciccone R, et al.(2008) A recurrent 15q13.3 microdeletion syndrome associated with mental retardation and seizures. Nat Genet 40:322-328.

Shively CA and Clarkson TB(2009) The unique value of primate models in translational research. Nonhuman primate models of women's health: introduction and overview. Am J Primatol 71:715-721.

Spurden DP, Court JA, Lloyd S, Oakley A, Perry R, Pearson C, Pullen RG, and Perry EK(1997) Nicotinic receptor distribution in the human thalamus: autoradiographical localization of $[3 \mathrm{H}]$ nicotine and [125I] alpha-bungarotoxin binding. $J$ Chem Neuroanat 13:105-113.

Stavinoha WB, Weintraub ST, and Modak AT(1973) The use of microwave heating to inactivate cholinesterase in the rat brain prior to analysis for acetylcholine. $J$ Neurochem 20:361-371.

Tietje KR, Anderson DJ, Bitner RS, Blomme EA, Brackemeyer PJ, Briggs CA, Browman KE, Bury D, Curzon P, Drescher KU, et al.(2008) Preclinical characterization of A-582941: a novel alpha7 neuronal nicotinic receptor agonist with broad spectrum cognition-enhancing properties. CNS Neurosci Ther 14:65-82.

Timmermann DB, Grønlien JH, Kohlhaas KL, Nielsen EO, Dam E, Jørgensen TD Ahring PK, Peters D, Holst D, Christensen JK, et al.(2007) An allosteric modulator of the alpha7 nicotinic acetylcholine receptor possessing cognition-enhancing properties in vivo [published correctio appears in $J$ Pharmacol Exp Ther (2009) 331:1146]. J Pharmacol Exp Ther 323:294-307.

Tribollet E, Bertrand D, Marguerat A, and Raggenbass M(2004) Comparative distribution of nicotinic receptor subtypes during development, adulthood and aging: an autoradiographic study in the rat brain. Neuroscience 124:405-420.

Vardigan JD, Cannon CE, Puri V, Dancho M, Koser A, Wittmann M, Kuduk SD Renger JJ, and Uslaner JM(2015) Improved cognition without adverse effects: novel M1 muscarinic potentiator compares favorably to donepezil and xanomeline in rhesus monkey. Psychopharmacology (Berl) 232:1859-1866.

Weed MR, Polino J, Signor L, Bookbinder M, Keavy D, Benitex Y, Morgan DG, King D, Macor JE, Zaczek R, et al.(2017) Nicotinic alpha 7 receptor agonists EVP-6124 and BMS-933043, attenuate scopolamine-induced deficits in visuo-spatial paired associates learning. PLoS One 12:e187609.

Welsby PJ, Rowan MJ, and Anwyl R(2009) Intracellular mechanisms underlying the nicotinic enhancement of LTP in the rat dentate gyrus. Eur $J$ Neurosci 29:65-75.

Wevers A, Burghaus L, Moser N, Witter B, Steinlein OK, Schütz U, Achnitz B, Krempel U, Nowacki S, Pilz K, et al.(2000) Expression of nicotinic acetylcholine receptors in Alzheimer's disease: postmortem investigations and experimental approaches. Behav Brain Res 113:207-215.

Whiteaker P, Davies AR, Marks MJ, Blagbrough IS, Potter BV, Wolstenholme AJ, Collins AC, and Wonnacott S(1999) An autoradiographic study of the distribution of binding sites for the novel alpha7-selective nicotinic radioligand [3H]methyllycaconitine in the mouse brain. Eur $J$ Neurosci 11:2689-2696.

Williams DK, Peng C, Kimbrell MR, and Papke RL(2012) Intrinsically low open probability of $\alpha 7$ nicotinic acetylcholine receptors can be overcome by positive allosteric modulation and serum factors leading to the generation of excitotoxic currents at physiological temperatures. Mol Pharmacol 82:746-759.

Williams DK, Wang J, and Papke RL(2011) Investigation of the molecular mechanism of the $\alpha 7$ nicotinic acetylcholine receptor positive allosteric modulator PNU120596 provides evidence for two distinct desensitized states. Mol Pharmacol 80: 1013-1032.

Wong DF, Kuwabara H, Horti AG, Roberts JM, Nandi A, Cascella N, Brasic J, Weerts EM, Kitzmiller K, Phan JA, et al.(2018) Brain PET imaging of $\alpha 7$-nAChR with [18F]ASEM: reproducibility, occupancy, receptor density, and changes in schizophrenia. Int J Neuropsychopharmacol 21:656-667.

Wong DF, Kuwabara H, Pomper M, Holt DP, Brasic JR, George N, Frolov B, Willis W, Gao Y, Valentine H, et al.(2014) Human brain imaging of $\alpha 7 \mathrm{nAChR}$ with [(18) F]ASEM: a new PET radiotracer for neuropsychiatry and determination of drug occupancy. Mol Imaging Biol 16:730-738.

Young JW, Crawford N, Kelly JS, Kerr LE, Marston HM, Spratt C, Finlayson K, and Sharkey J(2007) Impaired attention is central to the cognitive deficits observed in alpha 7 deficient mice. Eur Neuropsychopharmacol 17:145-155.

Address correspondence to: Dr. Xiaohai Wang, Merck Research Laboratories, Merck \& Co., Inc., 770 Sumneytown Pike, WP14-3393, West Point, PA 19486. E-mail: xiaohai_wang@merck.com 